TAX AVOIDANCE AND EVASION

A THESIS

IN ACCOUNTINO

by

Earl Bryant, Jr.

Approved

Texas Technological College

August, 1962 
IAX AVODDANCE AID IVASIOI

A Trisis

2.

II ACCOURTIIG

\begin{abstract}
Submitted to the Faculty of the Divinion of Graduate Studites of Texas Tochnologlcal Cellogo

In Partial Fulfijimant of the Reguiraments for the Degree of
\end{abstract}

UASTER OF BUSIUESS ADKINISTRATION

by

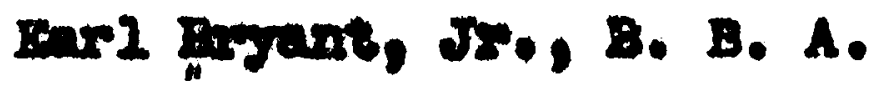

Big apring, remen

Arguat, 1088

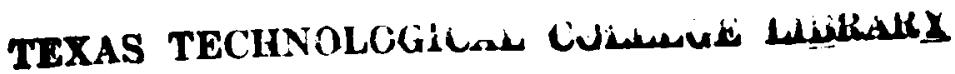

LUBBOCK, TEXAS 
1952

N...L

$\cos 2$

TABLE OP CONTINTS

CHAPTER

PAGE

I. IXTRODUCTION AND DEFINITION OF TIRUS UTED...... I

The Problem.......................... I

Statement of the Problem................. I

Importance of the $8 t u d x \ldots \ldots \ldots \ldots \ldots \ldots \ldots \ldots . . . .1$

Sources of data..................... 2

H1storical algniflgance of the problem..... 2

Definition of terms used.................. 9

Tax avoldance and evaston................ 9

Capital gains ........................ 8

Parsonal holding company.............. 10

II. THE INDIVIDUAL TAX PAYER................ 12

Capital gains .......................... 14

Proflt-sharing plans.................. 14

Stock options ...................... 15

A Panamantan aubsidiary ................ 17

Investments ........................ 18

Deferred calary ......................... 23

Expense accounts ...................... 25

Loans ............................. 26

Postpone Income to 1953 .................. 27

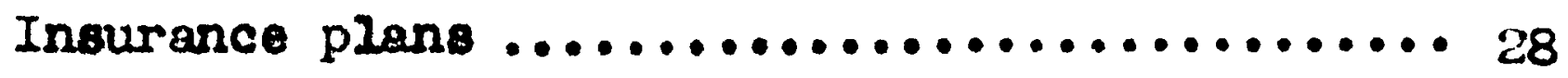

Stock dividends ........................ 29

Creation of trusta.................... 30 
III. THE PARTIERSHTP.

PACE

Advantage of partnemship for tax purpose8..... 34

Sale of interests.................... 34

Cap1tal galns and lossea................ 34

Federal income and excess-proflts tax...... 35

Family partnerahlp................... 36

Derintition of a partnar................. 36

How the family partnershlp saves taxes...... 36

IV. THE CORPORATIOR.......................40

Sale and lease-back.................... 41

Deduct1ble 10s8....................42

Rental deduction.................... 42

Combine a losing business with a profitable enterprise........................43

Dolng business abroad................. 45

Nonresident forelen corporations.........46

Subsidiaries...................47

Trading mostly abroad................ 47

Forelgn tax credit................. 48

Weatern Hemlsphere Trado Corporations....... 49

Corporations doing business in U. S.

Possessions........................ 50

China Trade Corporations................ 51

v. TAX ADVANTAGIS AND DISADVANTIGES IN A PROPRI.TORSTIP, PARTMERSHIP AND A CORPORATION....... 53

Genaral advantages and disadvantages....... 53 
Sale of Intereste.................. 54

Capital gaing and lossos.............. 54

Changing the form of business.......... 55

Transfer from a partnerohlp to a cor orathon......................... 56

Transfer from a corporation to a partnerbhip......................... 56

sale of a company................... 57

Proprietorsh1p.................... 57

Partnerahip...................... 60

Corporation...................... 61

Operating a lanlly business.............. 62

Operating as a proprietorship.......... 64

Operating as a partnership............. 64

Operating as a corpartion............ 65

VI.

The Federal istate Tax................. 66

Estate planning.................... 67

Eatates of from $\$ 1$ million upward....... 68

Estates of from $\$ 100,000$ to $\$ 260,000 \ldots . .68$

Fistates of from $\$ 250,000$ to $\$ 1$ million... 69

Excample of estate-planning............ 69

Working tools that may be used in estateplanning....................... 70

Gifts "inter vivos"............... 70

Marital deduction.................. 73 
$\nabla 1$

CHAPIER

PAGE

Trusts ...............76

VII. sumart .................... 77

BIBLIOGRAFH . . . . . . . . . . . . . . 80 
DNTRODUCTION AND DEFINITIONS OF TERMS USED

During the past four decades, tax avoldance and evaIon have become of paramount Importance to every tax payer In the Unfted States. is tax rates Increased, tax payers sought new mean of avoiding taxes. Wany turned to 1 llegal moans. The first attempt to prevent tax avoldance was made by Congress in the passing of the Revenue Act of 1932 whlch contalns mumerous provisions designed to prevent tax avo1dance and evasion. As Congress closed extsting loop holes In the tax laws by this act and subsequent acts, tax men have attempted to IInd new means of avoiding the conotantly $\checkmark$ rising taxes.

\section{THE PROBLER}

Statement of the problem. It is the purpose of this study to describe and 1llustrate some of the means of avo1dIng and ovading Federal Income taxes utilized by the two main classes of tax payers; Individuals and conporations. Also this study Includes methods of avolding and evading various miscellaneous taxes. This study does not cover all of the possible means of tax avoldance and evasion, nor does it recommend any of the methode described herein.

Importance of the study. "During recent years, tax 
payers have recelved relatively high salarles, but a small percentage of these high salaries has been retalned by the tax payer. Any extra portion of the salary that can rightfully be retained by him is of utmost importance to his economy.

The importance of this study may be emphasized by the ever Increasing pressure being applied on Congress to close exloting loop holes. According to estimates of the Bureau of Internal Revenue, tax evalon costs the Government \$1.5 b11110n. Individuals are responstble for the greater part of tax evasion. The latest attempt made by Congress to stop this loss of revenue was the passing of the Revemue Act of 1961.

Sources of data. Materials for this study were gathered from recent magazine articles published in several busIness and profosslonal magasines. Prentice-Hall's Eederal Tex Course was used to verify certain portions of these articles, also certain points were verifled by using PrenticeHall's Federal Tax Service. Several footnotes refor directly to the Internal Reverme Code.

Historical significance of the problem. In order to rully omphosize the increased and growing Importance of tax avoldance and evasion, a brief history of the Reveme ncte 
16 presented. 1

SPR

Reveme Act of 1913. Th1s act marks the beginning of the tax on Income in the Unfted States. The Act imposed a normal tax rate of one per cent on the taxable net income of every citizen of the United States.

An additional ourtax with progreselve rates was levled on the amount of an ind1vidual's net income exceeding $\$ 20,000$. The maximum rate of the income tax was seven per cent.

lievemse Act of 1916. The normal tax rato was increased from one per cent to two per cent. The surtax on income over $\$ 20,000$ was ralsed on a progressive scale from a maximum of $11 x$ per cent on incomes over $\$ 500,000$ to a maxImum of 13 per cent on incomes over $\$ 2$ million. The maximum rate of Income tax, as a whole, was increased from seven per cent to 15.

* Bavenue Act of 1917. The War Incom Tax Imposed a war normal tax of two per cent on the incomes of individuals and of four per cent on the incomes of corporations.

The taxes were a supplement to the Act of 1916 and brought the total retes to four per cent for individuals and alx per cent for corporations.

\footnotetext{
I Ratrier, Sidney, Amarican Taxation (New York: W. Norton and Company, Inc., 1942), p. 333.
} 
The now ourtax began at one per cent on the amount of the totel Income over $\$ 5,000$ and rose to 50 per cent on the amount over $\$ 1$ mililon. The maximum rate on income tax, 28 a whole, was increased rom 15 per cant to 67 per cent. An excese-proflta tax was imposed.

Reremue Act of 1918. This act Increased the tax load by about 250 per cent. The normal tax on the net incomes of all Individuals was fixed at $81 x$ per cent on the 11rst $\$ 4,000$ and at 12 per cent upon the remainder for the year 1918. For subsequent years these normal rates were made four and elght per cent respectively. The surtax rate began at one per cent on incomes over $\$ 5,000$ and Increased by one per cent for every $\$ 2,000$ increase of income from $\$ 6,000$ to $\$ 100,000$. For Incomes over $\$ 100,000$ the increase contimed at a smallar rate unt11 a maximum of 65 per cent was reached on the amount of an Individual's income in excess of $\$ 1$ million. The total tax on portions of income over $\$ 1$ million amounted to 77 per cent.

Corporations were taxed at the rate of 12 per cent of their net income for 1918 and 10 per cent for subsequent years. The excess-profits tax was also increased, but Individuals and partnerahips were no longer subject to that tax.

Reveme Act of 1921. The taxation of capltal gains was given epecial treatment by this Act. This act provided 
that capital gains should be taxed at $12 \frac{1}{2}$ per cent Instead of the high surtax rates of the provious years.

Normal income tax rates were kept at four per cent upon not income of $\$ 4,000$ or less and eight per cent on incomes in excess of that amount. Personal exemptions for heads of familles was ralsed from $\$ 2,000$ to $\$ 2,500$. The surtax rate was reduced to 47 per cent on income up to $\$ 100,000$ and then the rates of 1918 would apply. The excess-profits tax was repealed. The tax rates on corporations remained at 20 per cent.

Revenue ict of 1924. The normal income tax rates were reduced from one per cent upon the first $\$ 4,000$ of net Income and elght per cent on the excess to two per cent upon the first $\$ 4,000$, four per cent upon the next $\$ 4,000$ and $81 x$ per cent upon the amount over $\$ 8,000$. The new surtax rates began at one per cent upon the net income in excess of $\$ 10,000$ and rose gracueliy to a maximum of 40 per cent on the net income in excess of $\$ 500,000$. A special surtax rate of 50 per cent was placed on corporations.

Revemie Act of 1926. The normal income rates were reduced to $1 \frac{1}{2}$ per cent upon the first $\$ 4,000$ of net taxable Income, three per cent upon the next $\$ 4,000$ and five per cent upon the amounts over $\$ 8,000$. Haxtmum surtax rates became 20 per cent compared to 40 per cent in the Act of 1924 . 
The tax on corporate net income was increased rrom $12 \frac{1}{2}$ per cent for 1925 and to $13 \frac{1}{2}$ per cent for subsequent years.

Revemue Act of 1928. The normal tax and ourtax rates on Individual income remained the same as in the 1926 law. The tax on corporate net income was recuced from $13 \frac{1}{2}$ per cent to 12 por cont.

Bereme ict of 1932. The normal rates on net income of individuale were increased from one and one half per cent on the elrat $\$ 4, \infty 00$, three per cent on the next $\$ 4,000$, and five per cent on the remainder to four per cent on the first $\$ 4,000$ and elght per cent on the excess.

The 1932 surtax rates began at one per cent of the amount in excess of $\$ 6,000$ and Increased by steps of one per cent on each $\$ 2,000$ bracket of income unt1l they reached 46 per cent on the $\$ 98,000$ to $\$ 100,000$ bracket and 55 per cent on incomes over $\$ 1$ million. The total maximam tax rate of the tax Iaw was 63 per cent.

Revenue Act of 1934. This act placed a flat normal tax rate of four per cent on the flrat $\$ 4,000$ of Individual net income. The 1934 aurtax began at four per cent on net income over $\$ 4,000$ and rose to a maximum rate of 59 per cent on net income over $\$ 1$ mililon.

Revemue Act of 1935. The normal tax rates remained the same. The surtax was ralsed to 59 per cent on incomes 
over $\$ 1$ mililon and 75 per cent on incomes over $\$ 5$ mill1on. The tax on corporate net income was changed from a flat tax of $133 / 4$ por cent to a graduated basis from 12$\}$ per cent on not incomes not in excess of $\$ 2,000$ to 15 per cent on net incomes not in excess of $\$ 40,000$.

THE REVARE ACT OF 1936 THROUGH THE IEVLIUE ACT OF $1951 .^{2}$

$\checkmark$ Revemue Act of 1936. Corporate normal rates were revised and new ourtax on undistributed profits of corporations was Imposed.

Reveme Act of 1937. This act contained provisione to prevent tax avoldance.

Revenue Act of 1938. This act provided a reduction - In effective rate rom 19 per cent to $16 \frac{1}{2}$ per cent for corporations distributing their entire net income.

Revenue Act of 1939. This act eliminated princlple - of ourtax on undiatributad profits of corporations. It permitted last in, first out method for inventories.

Revenue Act of 1940. This act raised the tax of individuals in certain brackets by nearly 60 per cent.

Second Revenue Act of 1940. Th1s act Imposed a new

Frank A. Dunn and Robert B. Mitchell, Federal Tax Course (New Yorks Prent1ce-Hal1, 1952), P. 1005. 
excess proflte tax and increased normal tax rates on corporations having normal-tax net income in excess of $\$ 25,000$.

Revemse Act of 1941. This act increased withholding rates and increased excess profits tax.

Rereme Act of 1942. Thls act increased the individuals normal tax to $81 x$ per cent and increased the surtax rates.

Corporate normal tax rates remained the some, but our- tax rates increased to top of 16 per cent. Excess proflts tax rate set at a flat 90 per cent with a post-war refund equal to 10 per cent.

Current Tax Tayment Act of 1943. Th1s act placed in-

- dividual income taxes on "pay-as-you-go" basis by requirins that (1) employers withhola the taxes on income pald to the is employees and (2) certain individuale must estimate and pay their tax curing the year.

Revenue Act of 1943. This act reduced the Victory tax to three per cent. It increased corporate excess profits tax to 95 per cent.

Indifidual Income Tax Aot of 194. Th1s act reduced the normal tax to three per cent. It Increased the surtax rate and combined it with normal tax. It repealed the victory tax.

Tax Adiustment Act of 1945. Thls act reduced the excess 
proflts tax on corporations.

Revepue Act of 1948. This act was destgned primarily to reduce taxee for the individual.

Reveme Act of 1950. Inls act closed loopholes and Increased taxes for Individuals and corporations.

Excess Profite Tax Act of 1950. This act imposed a 30 per cent excess profits tax on corporate current earnings. The minimum credit of $\$ 25,000$ was atill allowed.

Revenue Act of 1951. Th1s act increased indivioual and corporate taxes. This act ralsed individual taxes about 11 to 12 per cent. It raised corporate normal tax rates from 25 per cent to 30 per cent and reduced them to $283 / 4$ per cent for the year 1951.

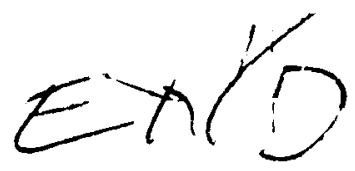

II. DEFINITION OF TERRIi USED

Tax avoldance and evaston. The general public uses these two termo/interchangeably, but there is a definsto distinction according to Lowe and Viright.

Avoldance is the use of speciflc exemptions, exclusions and decuctions allowed by law. Evasion on the other hand, is an attempt to cloth 1 ilegal deductions with a semblance of legal1ty.

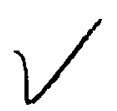

Capital gaing. The sale or exchange of a capital

3. Blake Lowe and John D. iright, Minimtzing Taxes on Incomp and Eatates (Now York: Barron's Publiahing Company, 1837), p. $x 1$. 
asset results in a capital gain. Thus, three elements are necessary to produce a capital gains (1) A capltal asset; (2) A sale or exchance; and (3) The sale or exchange must result in a gain. The Internal Reveme code defines a capltal asset as:

The term "capital asset" means property held by the taxpayer (whether or not connected with his trade or business), but does not include-

(A) Stock in trade of the taxpayer or other property of a kind which would be included in the inventory of the taxpayer if on hand at the close of the taxable year, or property held by the taxpayer primarily for ale to customers in the ordinary course of his trade or business.

(B) Property, used in his trade or business, of a character which is subject to an allowance for depreclation or real property used in his trade or business. (c) A copyright; a literary, musical or artistic composition; or aimilar property; held by (1) a taxpayer in whose hands the basis of such property is determined, for the purpose of determining gain from a sale or exchange, in whole or in part by reference to the basis of such property in the hands of the perBon whose personal efforts created such property.

(D) An obligation of the United States or any of 1ts possessions, or of a State or Territory or any political subdivision thereof, or of the District of Columbia, 1ssued on or after March 1, 1941, on a discount basis and payable without interest at a fixed maturity date not exceeding one year from the date of isoue. 4

Personal Holding Company. According to the Internal

Hevenue Code a personal holding company is defined as follows:

A corpor tion is a personal holding company if at least 80 per cent (or 70 per cent in certain cases where a corporation wa a personal holding company in a prior

\footnotetext{
4 Internal Reveme Code (New York: Prent1ce-Hell, Inc., 1951), p. 1152 .
} 
year) of 1to income for the taxable year 16 personal holding income. Personal holding company income includes:

(A) Dividends and anmities.

(B) Subject to specified exemptions, the following: Interest, royalties, gains from stock, security and commodity transactions, and rents.

(C) Certain income romi estates and trusts, personal service contracte and use of corporation property by a ahareholder.5

$\overline{6} \overline{\text { Frank A. Dunn and Robert B. Mitchell, Eederel }}$ Tax Course (New York: Prent10e-Hall, Inc., 1952), p. 3402. 
CHAPTIAR II

THE INDIVIDUAL TAXPAYER

1 An 1mportant question has been raised about how mach money a blg corporation hould pay its key executives. Large calarles, some as large as half a million dollars, are being challenged by stockholdar groups, politicians, and labor un1ons. "Fringe benefite" on top of other compeneations are coming in for criticism, some have been taken to the courts, but in spite of this, talk of sill highar pay and more "Iringes" for executives of corparations is atill growine otrong.

Some of the higheot pald men in the country complain privately that their salaries, though raised aubstantially, have falled to keep pace with taxes and llving coste. Boardo of drectors are looking for ways to glve new ralses that w1Il not be consumed by taxes. High executive salaries are favored by the existing tax 1aws. Corporations can glve high ralses to key executives without very much cash out lay. The government pays part of the b111.)

The following chart ahows how a corporation might glve high ralses to executives at a low cost because of $\operatorname{taxe} 8:^{1}$

1 "Ralsing Pay for Top liens Lay for Saving Taxee," U. S. News and Viorld Report, June 6,1952, p. 77 . 
It Costs

A Company

$\$$

2,593

4,147

8,257

26,272

69,644

130,820
To Pay

A Selary of

$\$ 14,403$

23,039

45,871

145,955

396,913

726,716
Of ihlch

Employee Retains

$\$ 10,000$

15,000

25,000

50,000

75,000

100,000

- Company aubject to excese-proflts tax.

(A corporation executive recelves a salary and bonuses of $\$ 400,000$ in 1951 . If he was married he had $\$ 82,488$ loft after taxes. If he recelves $\$ 400,000$ in 1952 , his salary, after taxes arops to $\$ 76,060$. But, when the company raises his pay to make up the difference, the government take 91 cents out of each dollar of the increase. To recelve approximately the same balary in 1952 he mat get a raise from $\$ 400,000$ to about $\$ 475,000$. If the company 18 subject to the excess-profite tax, 1to tax rate on the top layer of profit 1882 per cent. Therefore, the net cost of a $\$ 60,000$ ra1se would be $\$ 10,800$. The rematning $\$ 49,200$ would be pald, in effect, by the government;

(Corporations are looking for "fringes" that w111 offer some degree of tax avoldance for the Individual tax payer. Some corporations use ouch devices as: proflt sharing plans, stock options, deferred pay plans, Insurance plans, and other methods of increasing pay without increasing the tax burden carried by top executives and other employees. A few of the methods now being employed by corporations in 
behalf of their employees and methods being employed by indivicual tax peyers themselves are related in this chapter.

\section{A. CAPITAL GAINS}

Proflt-sharing plang. Current hlgh tar rates have encouraged this plan conslderably. The company paya/a stated percentage of the years profits into a fund in the name of the employee, payable to him at a later date, usually after retirement. The company gets a full deduction in the year of payment to the plan. The employee or h1s family would get a capital gain, if strict tax rules are complied with, and if he 18 pald his entire distribution when he leaves his job. Thls type of plan has govarnment approval, but strict tax rules must be satisfled. 2 !

(Employer oetting up profit sharling plans for the beneflt of their employees frequently create a trust to hold, Invest, and distribute amounts contributed by then under this plan. $)^{3}$

The following requirements must be met in order for Income recelved from such a twust to be tax-exempt. 3

1. The plan is for the exclusive benefit of employees or their beneflclarles.

8. The sole jurpose of the plan is to offer the employees or thalr beneficlaries elther (a) a ahare of the profits of the business or (b) an income after retirement.

\footnotetext{
2 J. K. Lasser, "Higher Incomes, HLgher Taxes," The Atlant1c Monthly, 289-3, ilarch, 1952, p. 65 .

3 Frank $A$. Dunn and Robert B. W1tchell, Fedorel Tax Course (New York Prent1ce-Hall, Inc., 1952), p. 3019 .
} 
3. The contributions or benefits provided under the plan do not discriminate in favor of employees who are offlcers, sharaholders, persons whose principal duties consist in eupervising the work of other employees, or highly compenseted employees.

4. The plan 18 permanent (that 18, as far as intent of employer is concerned).

5. The plan is in writing.

6. The plan 18 communicated to employees.

4 Stock options. (Stock options are a fevored rethod of avoiding taxes. The employee cannot do it by himself, but the employee can Ereatly assiot in the avo1dance of tax by the use of this plen.)

Several large corporatione have plane whereby they sell stock to employees at current market prices or at a small pereentage below market price. The company makes provlstons for loaning the employee the purchise price of the stock at low Interest rates or sells it to hin on a long term payment plan.

In these plans, employees are often credited vith dividends to reduce the amount due. In some crisco the purchaser my have the right to discontinue payment if the market price of the stock fluctuates.

(The baslc 1dea behind the stock option is aimple. A company gives an omployee an option to buy a certain amount of its stock at present market prices or at a ama alscount from present market prices. At some ruture date, the employee can woe the option, he cashes in when the market is right. To escape tax, the option must be 85 per 
cent of market price at the time it is given. The exployee pays no tax on any gain unt1l ho sells the stock. He then paye the 26 per cent capital galno rate.

An executive of a company can buy a large number of shares and when he Alsposes of the stock he makes a capital gain. The straight income tax on his gain would be two or three tims the capital gain rate. 4 , The following chart shows how large companies are currently granting stock options: 5

$\begin{array}{clc}\text { Number } & \text { Number of } & \text { Option Prices } \\ \text { of } & \text { Eligible As Par Cent of } \\ \text { Shares } & \text { Employees } & \text { Market Price }\end{array}$

0. S. Steel

Sinclair 011

Sears, Roebuck

American Alrline

Plttsburg Plate Glasa

Culf 011

Standard 011 (N. J.)

Republic Steel

union 011 of Calif.

Bond Stores

Colanese

Jones and Laughlin

Loewr'

Allogheny Corp.

St. Reglo Paper

United Paramount

$1,300,000$
598,700
500,000
500,000
450,000
400,000
$300, \infty 00$
300,000
$300, \infty 00$
$300, \infty 00$
$300, \infty 00$
$300, \infty 00$
250,000
250,000
$250, \infty 00$
$250, \infty 00$

300
200
40,000
30
40,000
95
125
75
30
659
45
100
6
10
100
50

100

100

85

85

85

85

95-100

95

100

95

95

100

100

100

95

95

An option might work like this a corporation sets asde 2000 shares for one of 1 ts offlcers at $\$ 95$ when the atock Is selling on the market for $\$ 100$ a ahare. Several years later, the stock is selling for \$125, and the offlcer

T. K. Lasser, "H1gher Incomes, H1gher Taxes," The Atlantic Monthly, 189-3, March, 1862, p. 65 .

6 IbId., p. 65. 
dec1des to buy. He buys h1s 2000 shares for $\$ 180,000$, but thay are now worth $\$ 250,000$. Elght months later, he sells at $\$ 125$, mtting $\$ 60,000$. At cap1tal gain rates, the most the government can take of the $\$ 60,000$ 1s $\$ 15,600$. At regular income rates the government would take much more of the $\$ 60,000$. The higher the income level the greater the advantage of this method becomes to the officer of the corporation.

A Panamanian subsidiary. The forming of this oubeldiary made the heed IInes and caused an extended Investigation into the whole matter.

A group of men formed two corporations, one an Amerlcan company and the other a Panamantan subs1diary. Stockholders put up $\$ 100,000$ of their own money, and borrowed $\$ 10$ milition from an insurance company. They bought five ships from the Maritime Commission, raglotered them in Panama, and the Panamanian Corporation leased them to a blg American 011 Company.

Rental fees on the ships were used to pay off the 10an. But the American parent corporation ahowed no profit and paid no tax. The Panamantan company did not pay American taxes on the income it received. After most of the loan had been pald, the corporations sold out at a proflt of $\$ 2.8$ all1102. On that, the stockholders pald cap1tal-galns taxes. The principal stockholder put up $\$ 20,000$ and got back 
$\$ 270,000$. On the profit he paid a 25 per cent tax, 1951 capital gain rate.

Simliar arrangements like this might be worked out by other taxpayers who have a I1ttle capital and ways and means of obtalning some type of assets that could be sold in a like manner.

Imyestmants, 6 Not 011 investments are used for cap1tal-gains purposes, but a favored use of them are for cap1tal-gain purposes. For that reason, and for organlzation purposes they are pl ced under the heading, Capital-Gains. Hany taxpayers have advised their stockbrokers that they are looking for capltal-gains only and that they can not afford dividends. A taxpayer making around $\$ 30,000$ could afford to buy and sell stock and pay taxes on his proflts at capital-gain rates.

The three post-Korea Increases have virtually made It prohibltive for high-balarled groups to recelve other income rom Investments. The only solution would be for these texpayers to seek "tax-ahlelded" Investmante.

The principal tax refuges were dellberately provided by Congress, preaumbly to further some real or fancled economic or soclal purpose. Congress also has created means of avoiding taxes unintentionaliy. Some means have been

OJohn P. AIIIBOn, "How Investore Can Cut The1r Taxes," Forture, 45, April, 1952, p. 96. 
provided by the wording of the tax laws, whlch are not always clear and by fallure to foresee the ways in which plaulble tax theory :111 work out in practice. Probably the nost widely used methods of avolding taxes is the sale or exchange of capital assets held over s1x months. The tax on auch galns can not exceed 26 per cent compared to 82 per cent on ordinary income, thus giving the taxpayer a large saving in taxes if he becomes eliglble for the capltal-gain rate.

The complete tax exemption given to interest on state and municlpal bonds is another well-known. "loophole" In the tax laws. lany lawyers eay that it would take a constitutional amendment to eliminate this provision of the present tax law. The followlng chart showe the advantages of an investment in tax free bonds.?

If you have a tax- Your investments And your investments able incom this have to earn this have to earn this big after exemptions much in order to much to equal your and deductions..... equal your yleld yleld on a 2 th $^{9}$ tax from a Ifo tax free security free bond

$\$ 10,000$ 20,000 30,000 40,000 50,000 75,000 100,000 200,000

$$
2.42 \%
$$$$
3.41
$$$$
3.95
$$$$
4.84
$$

6.00

7.89

13.64

15.00
$4.03 \%$

5.68

6.58

8.06

10.00

13.16

22.73

25.00

p. 83.

7 "Lose With Prof1t," Business Lenk, Yay 5, 1951, 
To a taxpayer whose taxable income on a jolnt return Is $\$ 40,000$, a 2 per cent exempt yield is equivalent to a 5.26 per cent taxable yield and a 1.75 per cent exempt yleld 18 equivalent to a 4.61 per cent taxable yleld. To the higher bracket taxpayer, the small tax free ylelds are equivalent to as high as 25 per cent taxable ylelds.

Investments in 011 and gas drilling ventures, long used in the west, are another tax avolding refuge. The venture offers write-offs of part or all of the costs agalnst other income, and also 272 per cent depletion on 011 and gas runs if the drilling operations are successful.

The coste may be wricten off at the invegtor's election-whether or not oll is found-are those that are incurred in connection with the drliling operations and are not invested in assets with a salvage value. They are the so-called "Intanglble" arliling costs; wages, fuel, repalrs, hauling, supplles, etc. These Items may be deducted thoush the arililin is done by an outside contractor who is paid a lump aum for completing the well.8

These ventures are best oultable to high-1ncome-lowcapital taxpayers. Intcrtalners offer a good example of this class of taxpayer.

By prop:- timlis of drilung operetions, such investors can put up parts of their salary that they would otherwise use to pey current income tax instaliments. If the venture Is a loss curing the same year, income for that year is reauced by the loss; if the venture pays off and income in John P. Allison, "How Investors Can Cut Their Taxes," Forture, 46, p. 86. 
future years 18 Indlcated, the Invested tax money, part of which is writton off, may be replaced by a loan against the Individual's share in the venture.

The investor may fine in securities several opportunities for obtalning a partially or holly tax-free anmal yleld from corporations whose distributions constitute a return of capital in place of ardinary income. This method of distribution is made possible by the otatutory definftion of a dividend as a distribution of of a corparation's accumulated or current earninge. The payment, if made by a corporation having neither accumulated nor current earnings, is not a dividend and is not taxable as income.

Investors may also find excellent tax avolding possibilities in mortgaged real estate. Many properties, becaune of rent control or for some other reasons, offer little or no return after operating expenses.

A highmbacket investor may find excellent possibllItles if the property can be purchased for a silill cach payment over the mortgage providing that the mortgage amortization Is not too large. One reason is that dopreclation is measured by the grose cost, not the amall cash Investment. An Investor might purchase a building carrying a Iongterm mortgage. Amortization of the mortgage 18 small and the Interest rate is 10\%. The rents are eaten up by operating expenses, interest, and taxes. Suppose that the roperty can 
be purchased for a small amount of caah over the mortgrage, and the majority of the gross purchase price is allocable to the builaing-the depreclation 1s large and the mortgage amortization 18 arall. For the taxpayer whose income can absorb $2108 s$ due to depreclation this might be one method of galning tax tree income.

The high-bracket real-estate buyer nay get another break if he affers a 108 on a real-estate transaction. Frorlte from sales of realmestate are taxed as capital galns, the 2080 from euch transactions may be charged in full againat ondinary incom, unless he has galno of the same type for the year.

The regulated-investment company can also be a device for avolding taxes. These companies are not required to pay capltal-gain tax if they distribute their long-term profits and their other inoome.

The atockholder's are allowed to treat that portion of each dividend which is attributable to the long-term proflts as though it were long-term gaino they themselves realized. The stockholders are not required to hold stock in the company for over s1x months. They may buy the stock a ahort time before the distribution 1s made and otill treat it as a long-term galn.

Tax avoldance opportunities are also offered by dofault bosds, such as the Hissour1-Kansas-Texas R. R. 5's of 
1867, on wich Intareat arrears are being gradually pald off. The Intereet 18 a return of purabase price and 18 not taxe ab1e. The bonde are not terable unt11 8010 and then at the capital-gains rate.

\section{B. DEFERRID SALAPY}

(Deferred pay plane offer many pousibliltles of tar aroldawe. The basic thoory behind a deferred pay plan 18 to opread pay out over a period of yeare, thus eaning the tax burden The type of contract given to uliton Berle by the National Broadcasting Company may lay the framo work for Nuture possibilitien in this fleid.

The new contract paya Berle $\$ 60,000$ a year for thirty pearef Barle works torenty years and stays on the payroll for thirty yoare. Bafore the contract Borle's ealary was estlmated at $\$ 23,800$ a performance, at that rate, he could make the $\$ 1,500,000$ in three yeare, but taxes would be taking 01080 to 85 per cent. 8 )

Lany types of deferred ealary plans are avallable for the person mose company will cooperate. Many taxminded and securlty-worried companies are trying to get monay out of a hloh-incomo-tax year over to some lowarIncome-tax year. The princlple 18 to eimply spread today's

J. K. Lasser, "How To Ra18e Execut1ves' Take-Ham Pay Under Vage Contro I and Tax Laws" The Journal of iocountency, 03-2, Bob., 1952, p. 166. 
high carning powers into later years.

Many men turn down current salary offers bayond their greatest dreams to gamble wlth promises to pay to tham-or sometime to helrem-ten or twenty years 1ater. Some consent to pay in the long deforred period based on carnings, Bales, or dividende then avallable to stockholders.

To avold immediate tax to the employee, the following agreements should be considereds 10

2. Agreenent of the employee to give up all hIs compeneation if he quits or is flred before his deferred pay 18 due.

2. Agreament by you not to compete or to work for a competitor curing the retirement period, when you might lure away Important accounts.

3. Agreoment to remain avallable for consulting or advisory cervices.

4. Agreement to waive the defarred pay if the company' earnings or sales or some other index of 1ts wellbeing fall below atfpulated levels in the pay out perlod. of these arrangements, probably only the first is Iully foolproof. In other cases, condition within each business govern the court's attitude. The main thing is to avold establiching a nonforfeltable economic gain for you

$$
\text { IO J. K. Lasser, "HLgher Incomes, HLgher Taxes," }
$$
The Atlantic Monthly, 189-3, March, 1952, p. 65. 
that can be taxed immediately. II

\section{EXPENSE ACCOURTS}

Some companies allow executives to use expense accounts to increase take-home pay. The expense must be required by the business before any advantage can be given to the executive.

The Treasury Dopartment has not attompted to tax employees when a company does these thinges

2. Croup term Iife inourance, where the omployer pays the premium, the employee deelgnates the beneflelary.

2. The employer's binding agreement to pay an amount up to $\$ 5,000$ to your beneflelary upon your death.

3. Group modical care and hospltallzation in cases where the employer is allowed to deduct premium payments as a legitimate business expense.

4. Medical examinations or treatments furnishad by the employer.

5. Accleant and health inaurance, the employer paying the promiun.

6. Permision to use a company automoblle or plane for personal use.

Where posalble, corporations pay the ches for an

21 J. K. Lacser, "How to Kalse Execut1ves' Take-Hom Pay Under Wage Control and Tax Laws," The Journal of Accountancy, 93-2, p. 166. 
executive in clube to which the company thinks he should belong. In som instances compantes provide cheap rent in company owned owellings and also pay utillties, repalrs, and service to keep the house in good shape. If possible a com pany might pay all entertalning and traveling expenses for the employee. 12

\section{LOANS}

If the texpayer could make arrangements to draw part of his pay disgulsed as a repayable loan it would be one possible way of evading taxes. There are several waye in which debt financing would afford a mans of tax avoidance for the taxpayer. Drawing pay in the guise of a rapayable Ioan does not have the approval of the Bureau of Internal Revenue.

One case, which was Investigated by the senate, went I1ke this, an enterprising business man dolng business with the help of the Reconstruction Finance Corporation, acquired extensive holdinge in various business enterprises. These Included Insurance, a brewery, 011 wells and other holdings. it ith a small salary he bought hls wife an expensive fur cont, an exponolve home and lived well.

The senators discovered that he had borrowed $\$ 135,000$.

12 J. K. Lasser, "H1gher Incomes, Higher Taxes," The Atlantic konthly, 189-3, March, 1952, P. 65 . 
They thought this ras income. Salarfes or fees are taxable Income. Borrowed money is not taxable as income. But, when a loan goes bad, the lender can charge it off against taxable Income as a bad debt. If the plin worke, the lender 18 protected and the borrower comes out that mach ahead. Only the Government 108es. 13

An individual may use debit financing in ordor to charge off the interest paid againat his taxable income. Iutin is a logitimate business traneaction.

E. POSTPONE TNCOME TO 1953--PREPAY 1953 EXPENSES IN 1952

If you can afford to take $108 \mathrm{~s}$ money th1s year, you can get it back next year, possibly at less tax cost. Tax experts point out two ways to plan your affairs to get a maximum break if there is a tax cut in 1953.

1. Postpone 1952 income to 1853.

2. Prepay 1953 expenses in 1952.

For example if you are drawing $\$ 30,000$ a year, there 1s no reason why you could not arrange to draw $\$ 20,000$ this year and $\$ 10,000$ next year. There 19n't any advantage unInss taxes go down or that you expect to be in a lower bracket in 1953.

You can anift any income into 1953 that you do not have a right to this year.

LS "How Taxes are Avolded, U. E. Nerrs and World Report, March 21, 1951, p. 56. 
Additional compensation, Chrlstmas glfte, and bomseo are examples of this type of income, provided that there is no understanding that the noney is opecifically cue this year.

If you make a new contract requiring some performance by you in 1953, attempt to have most of the payments postpond until then.

Deduct any 1953 business deductions that can be prepaid in 1952. Thls includes contributions, taxes, interest payments, and medical and dantal costs.

State and local taxes are another example-pay both your 1952 and 1953 taxes in 1952.

It mlent be wise to borrow money, if you do not have 1t, to make these prepayments. This gives you a double deduction in 1952--prepaymento and interest on the borrowed money. 14

\section{F. INSURANCE PLANS}

Inwarance plans offer another way in wh1ch you may get more not gain out of a raise.

For Instance if the company was going to give you a $\$ 10,000$ raise, 1 would put what the $\$ 20,000$ would cost 1t, net after texes, into an anmity or endorment policy. The

\section{4 "Start Getting Ready For Lower Taxes," Euninese} Week, May 3, 1952, p. 87. 
amount of cost to the company would he determined by the tax bracket that it was in. For a company in the 82 per cent bracket, the cost would be as little as $\$ 1,800$.

The Insurance pollcy, naming the employer as beneIlelery, serves to underrite retirement pay for you.

his long no you aren't given ang right to the poliey or Its proceeds or named the benerlclary, you will not be taxed on any part of the annual premium payments.

The employer is allowed to receive the procseds up to the amount of h1s investment before he faces any tax 11ab111ty. When the proceeds are pald to you, in form of retirement pay, the employer can decuct them as a business expense.

You have to pay taxes on what you recelve, but your Income will probably be lower at that time. If you die before you have recelved the asreed number of paymenta, the flrst $\$ 5,000$ of the remaining payments go to your fam1ly tax Iree. 15 !

\section{G. STOCK DIVIDEATDS}

Stock dividends are becoming increasingly popular as a tax aroldance device.

If stockholders recelve a dividend in the same class of stock--common stock holders recelve adaltional common--

\footnotetext{
15 "Cut Texes-Save for Future," Bus1ness ick, February 23, 1952, p. 141.
} 
the courts hold that the distribution 1s not taxable. If common atockholders recelve a stock divident of preferred stock, the distribution is tarable. If a corporation has only one clase of stock, distulbutions to any or all stockholders are not tascable.

Stock difidends cut taxes in this manner: a corporan tion has $\$ 2$ mililion of earnod aurplus that it wants to distribute to 1ts stockholders. If cesh alvidends are peid the atockholders will be required to pay ordinary Incom tax rates on the distribution. If the company has only common stock outotanding 1 t transfers $\$ 2$ million of earned arplus to 1 ts capitel stock rccount and distributes $\$ 2 \mathrm{mll}-$ IIon of common stock to its stockholders as a tax-free div1dend. At a later date the stockholder sell the additional stock, paying only capital-gain rates. The difference between ordinary income rates and the lower cap1tal-gain rates offer quite a seving to the stockholder. 16

\section{H. CPEAATION OF TRUSTS}

One mall businessman protected his capltol and provided financlal securlty for h1s chlidren by creating trusts.

He tranoforred a amall tract of coal. Iand and another

16 Ha11 Street Journal, June 4, 1952, p. 1 . 
plot of Iand to the troutes wth the ascurance that the truste

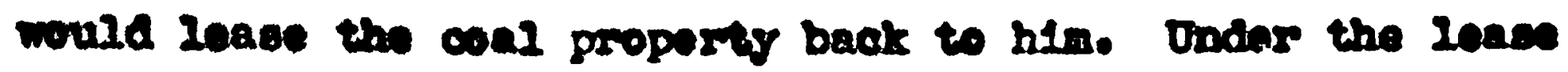
the businestuan mined conl for sive yeare, on a royalty basle.

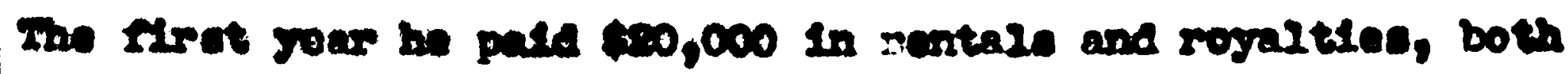
cacuotible from hle taxnblo income.

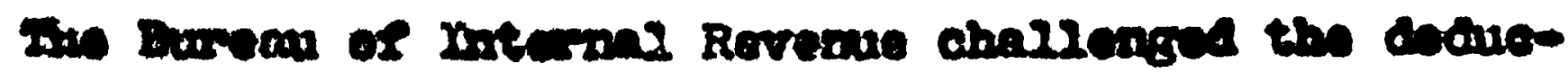

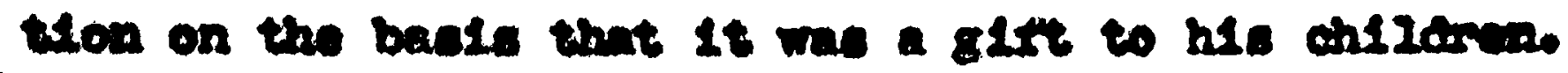

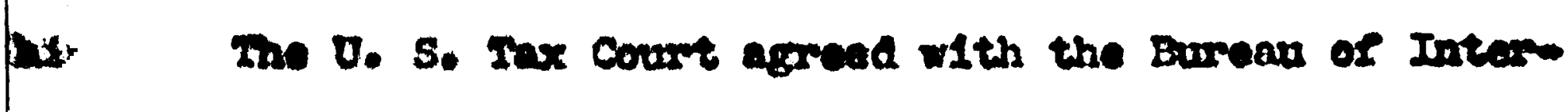

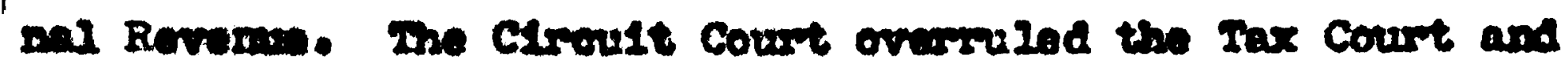
allowed the oncoution.

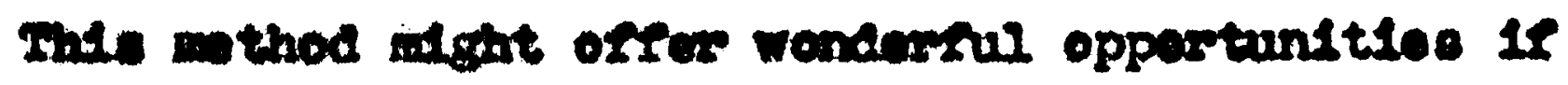
one has the property and crentes the truet peoperesfo

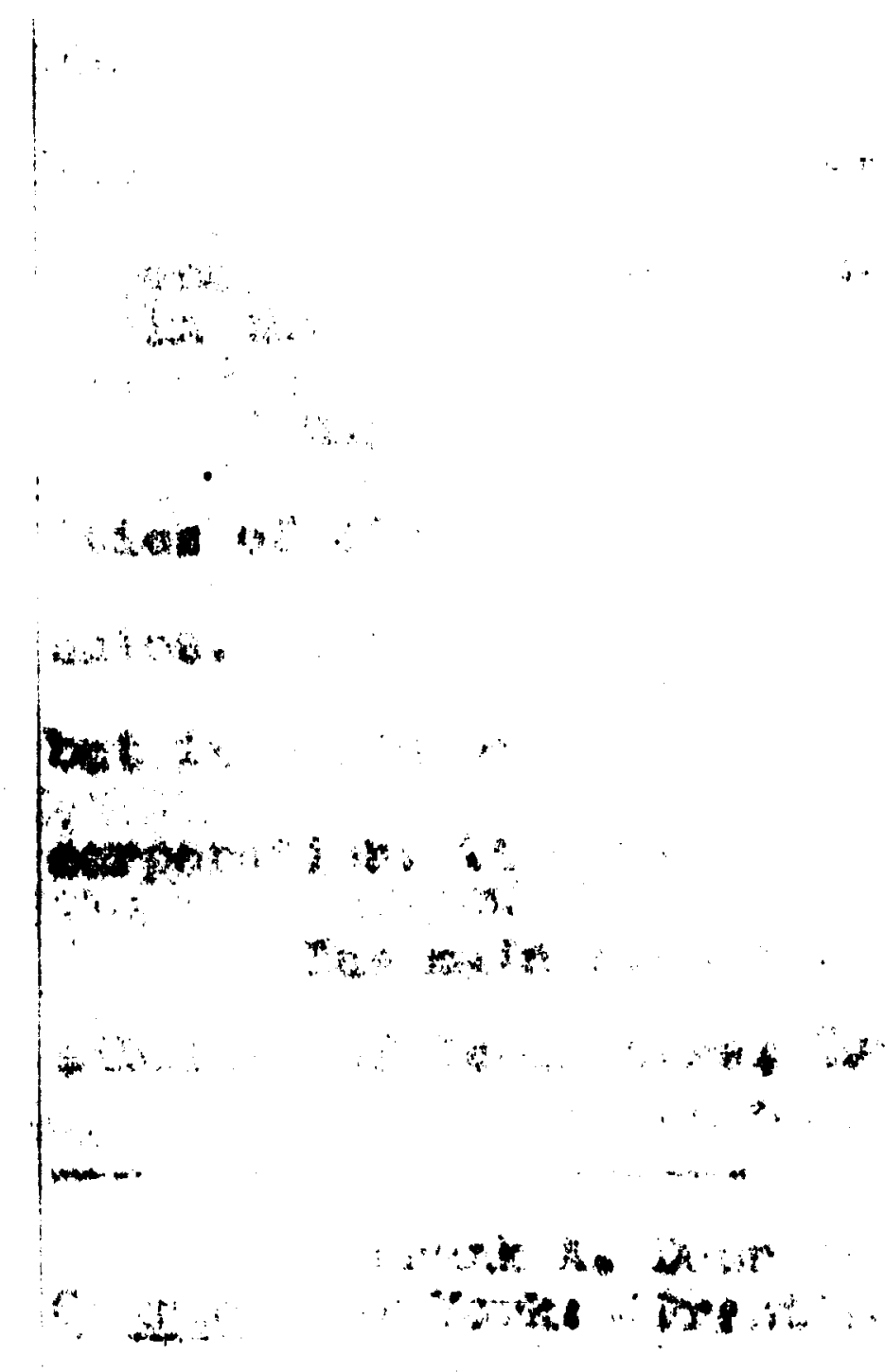


THE PARTMERSHIP

Partnerah1pa, as such, are not subject to income taxes. Each partiner mast include in his individual return, his distributive ohare of taxable income appearing on the partnorship return wether or not actualiy distributed to him.

The Internal Revenue Code does not speciflcally define the term partnership. It does classify certain business organtzation a partnerahipe.

To constitute partnership as judiclally dorined, there mat be (1) an assoctation or joining together of the parties to carry on a businoss enterprise, which requires, of course, express or implied consent to the arrangenent by all the parties who are partners, (2) a contribution by each of property or servicep; and (3) a comminity of interest in the profits. 1

(Many corporate owners are looking Into the possibll1t1es of dissolving the corporation and setting up partinerahips. Inis could be done if there were a few stockholders, but it would be virtually impossible for some of the larger corporations to convert to partnerahips.

(The in reason for this sudden 1nterest in the possibility of lower taxes due to the nature of partnerships.

1 Frank A. Dunn and Robert B. Mtchell, Fodered Dex Course (ilew Yorks Prent1ce-iiall, Inc., 1052), 2001 . 
(Suppose a corporation with three stockholders in 1952 had a net incom of $\$ 18,000$ before income taxes and alarles. The corporation has only three employees, the three stockholdere. Each receives a salary of $\$ 4,000$ a year. In computing a corporation's net income, ealaries are deducted. The company pays taxes on $\$ 6,000$. The corporation's tax on $\$ 6,000$ is $\$ 1,800$. The preant tax rate 1e $30 \%$ on 1ncome of $\$ 25,000$ or 1008 . The corporation paye a dividend of $\$ 3,000, \$ 1,000$ to each stockholder. Wach stockholder mat pay individual income tares on gross 1neom of $\$ 5,000$. For the purpose of 11lustration assume that each etockholder is married, has two dependents, takes the $10 \%$ atandard decuction and files a joint return, the ir combined tax b111 is $\$ 1,398$. The combined Federal incom taxes of both the corporation and stockholders will be $\$ 3,188, \$ 1800$ plue $\$ 1,398$.

Now suppose these three individuals had operated the business as a partmerahip. The partnershlp is not allowed to deduct alaries as an operating expense. Each partior would be taxed on one-thind of the income of the partnerahip. The combined Federal incom tax of the three partners would be $\$ 1,998$. This would mean a saving of $\$ 1,200$ in the total tax b11l. Thls difference is due partly to the Government's double taxation of dividends alstributed from earnings and 
the tax brackete of Individuals.2

\section{A. ADVANTIGE OF PARTMERSHIP FOR TAX PURPOSESS}

Sale of Intereste. When an Individual propaletor $80118 \mathrm{~h} 1 \mathrm{~s}$ business he usualy oells it as a single unit, but he cannot report it as the ale of a oingle unit, he must apportion the selling price between two classes of assetem-"capltal" or "ordinary". It would be a distinct advantage to the taxpayer if he could appostion the total sales price to capital assets, because of the capital-gains tax rate of 26 per cent compared to a much larger rate that would be applied for the ordinary assets--inventorles, etc. When a partner sells his interest in a partmerahip he sells a single untt, too, but he does not have to apportion the sales price between different assets. Ifo pays the capital-gains rate of tax on the ale of hie interest. 3

Capltal galng and 20osed. The partnerahlp's and the Individual's capital gains and $1085 e s$ are treated in the same manner. Each partmer treats hia distributable ahare of partmerahip capital gain or $108 \mathrm{~s}$ as his own indivicual capital gain or 2085 .

In the case of a corporation's capital gains a 14, 1951, p. 73.

2 wa11 Street Journal, June 18, 1952, p. 1. 14, 1951, p. 73. Soften the Tax BIow," Buginess "eek, July 
different method of bandling capital gains is required. A corporation's capital gains may be offeet by its own capital 108se8, but the stockholder cannot offset corporate $108 s e 8$ agalnet his personal capital gains. The corporation recelven the benefit of a Iower effective rate under the alternative mothod on its not long-term capital gains in excess of any net short-term capital $108 \mathrm{ses}$, but the excess of long-term capital gains will again be taxed to the stockholder as ordinary incom, where distributed by the corporation as atvidends. 4

Eadaral income and excess-proflts tax. Partnorsh1po are not subject to excess-profite tax levied on corperations. Partinerahips are not abject to double taxation as are corporations. In the beginning of this chapter is an 11luetration on how three individuals would save $\$ 1,200$ in income taxe by conducting their business as a partnerohlp rather than at a corporation.

Another advantage would be the use of a partnerahip to oplit up incom among members of a family-a family partnerahip. Family partnershlps are alscussed in the lattor half of this chaptor.

\footnotetext{
Frank A. Dunn and Robert B. U1tchell, Eederal Tax Coures (How Yorks Prontice-liall, Inc., 1952), p. 3180.
} 


\section{B. FALILY J'ARTNERSIIP}

The Reveme ict of 1951 provided new ways of taxsaving by the use of family partmership. After the act of 1951 was passed family partnerahips have becom preferable to the closed corporation, from a tax standpoint.

The introduction of income-splitting in joint returns by the Reveme Act of 1948, has made the husband-wife partnersh 1p unnecessary.

Before the act of 1951 the Bureau of Internal Reveme often falled to recognize, for tax purposes, partnershipe with chlidren as a device to avold taxes. Parents would tranafer high bracket income to chlldren's low bracket of tax.

Defintion of a partner. Under the 1951 Iaw, a partner is recogntzed for tax purposes if he owns a capltal Interest in a partnerahip in which capltal produces incomo to a major degree.

Age is not a factor in the legal definition of a partner. A young chlld is just as elfgible as an odult. How the family partnershin saves taxes. You savo money when you ahlft income from high tax brackets to lower tax brackets. For example: Hr. Jones, a married man with one chlld owns a sole proprletorship that nets an Income of $\$ 4,000$ a year. Mir. Jones changes the business 
Irom a cole fropmetorshlp to a partnershlp and given his con an interest that transfers $\$ 8,000$ of business income to h1s son.

For tax purposes the $\$ 8,000$ becomes $\$ 6,600$ - the son Is entltied to his omn $\$ 600$ examption and at least an $\$ 800$ -tendard deduction, and the tax Ilablilty on the $\$ 6,600$ would be $\$ 1,720$ for 1952 .

The father $1080 \mathrm{~s}$ the $\$ 800$ exemption for h1s on under the partnership arrangement, but the tax savings on the $\$ 8,000$ will more than offaet the tax value of the lost exempt1on.

The new law requires that glfts of family portmership Interests be respected, but the Bureau of Internal Reverue may question the gift. Is it a gemine gift?

Any gift wade within a family hould be arranged so thet the following points can be provens

1. That the person making the gift is legally, mentally, competent to do so.

2. That the one who recelver the Elft 18 legally competent to do so. There is no age qualification, only the legal compatance reculrement.

3. That absolute transfor of $t$ itle and control was made.

4. That the done accepts the glft in good faith. Oxdinari2y, partberahip incom can be split any way 
the partinas agree, but the Revenue Act reotolote allosation

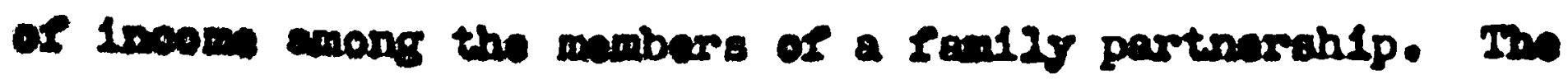
act oot up these two ruies restricting the allopation of

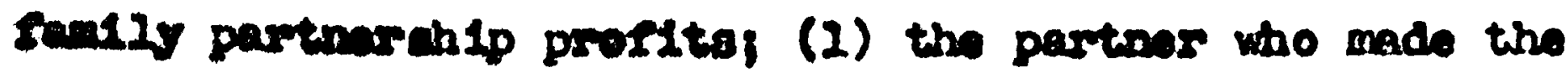
Dift wut take a reaconable partion of the proflte befors they are distributed to the remaning partmers and (2) the partinar who recelved the glft of the partarablp interest cannot recelve a greater ahare of prorlts than the purtion attributablo to his crpital. The restriction apply to the tumadate fanty group only. 6

A man tho is operating a bualness as a cole proprlo etorahlp my take his wife and children into the businose with his as partwers. If he has a wife and two chlidren he make an equal bona flde glft to each of then of a 26 per eent interest in the businese.

A partharahip agreanent is antered into with each patsing in his 26 por cent interest as capital and with each charing in the proflte and 20880 in acoordance with ils eapteal contribution. The conor of the partncrahip intarests wy be contgnated the managing partiex in the agreannt, and operate the buelnes as he ald before. The only change would would be the nam of the bueinese in ordor to chow that it was now a partanahip.

\footnotetext{
2. 1081, p. 84.

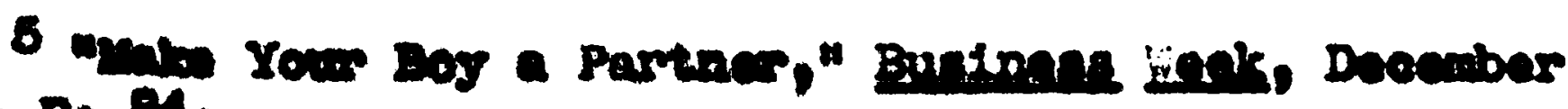




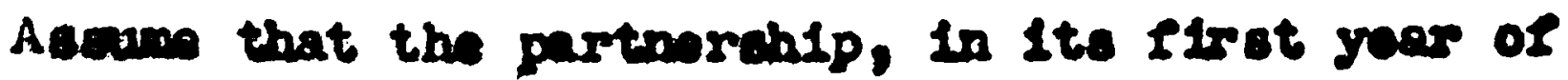
operation as woh, had a nt income of $\$ 60,000$. Acoerding to the partherchip agremint, each partmer's chare is 12,000. Before the Reverue Act of 1051, this partacentp nould probably not have been recognized by the Bureal of Intermal Rerame. Under the feveme Act of 1951 the part$+$ porahlp w12l be reopontzed, but the comileatoner will probably change the allocation of inoome. He would glve the partnormanager a reacomable salary and then distribute the romalnane of the incow enong the four partwers. 6

is 1

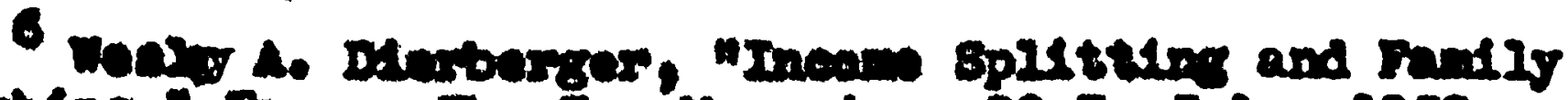

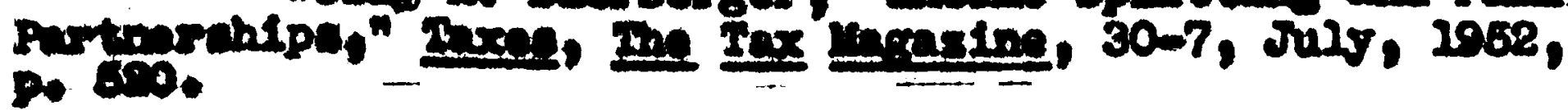


THE CORPORATION

The ordinary business corporation 18 subject to three taxes: normal tax, surtax, and excess profito tax. Although most small corporations are exempted from the excess-profits tax by the $\$ 25,000$ speciflc exemption, many large corporations are eubject to it and in addition, a apecial aurtax may be imposed upon corporations improperly accumilating surplus.

Many organizations, according to Income tax law, are taxed a corporations. Such organizations as joint stock companles, business truste and sometimes a limited partinaranlp may be classified as corporations, depending upon their characteristica.

Some corporations are elther wholly exempt or part1ally exempt. Such corporations as Fraternal Beneflt Societies, churches, and cemetery companies are wholly exempt.

Partialiy exampt corporations mist pay a tax on net Income over $\$ 1,000$. These include labor organizations, charitable or religlous organizations, etc. 1

1 Frank A. Dunn and Robert B. MItchel1, Federal Tax Course (Now Yorki Prent1ce-Hall, Inc., 1952), p. 3103. 
A. THE SALE AND LE . . BE-BACK

(In the sale and lease-back arrangement a corporation needing working capital, selle its property-ortan to a non-profit institution-and leases it back for a long perlod of time. Th1s arrangement will usually provide more net capital than other forms of debt financing.

In high excess-profits tax years, corporations may find six advantages in the sale and lease-back deal:

1. Rent payments are fully deductible under the 1098e8.

2. The deprectation decuction is not permitted after the property is sold, but the rental payments could easly be more than the depreclation deduction. The rental decuction runs for the lease period.

3. It Is legitimate for the lease to require the tenant to pay such deductible expenses as: real estate taxes, alteration costs, repalrs, and mintenance costs.

4. The Bureau of Internal Revenue arguments over the depreclation allowance is ellminated.

5. Profite on the use of the cash secured by the - ale of the property may more than compensate for the interest figured in the rental.

6. The rental payments include a deduction for underdeveloped land, otherwise depreclation is not allowed on the land.) 
There are two factors imvolved in sale and leaseback arrangements; (1) deductible 1088 and (2) rental deductions.

Deductible 10s8. Here is an example or how one corporation used the sale and lease-back deal to establiah a decuctible 1088 .

The corporation owns some property that 18 required for its business. The property has a book cost of $\$ 120,000$, but the value has declined and it is now worth $\$ 30,000$. The corporation sel1s the property for $\$ 30,000$ and immedlately leases it back for 20-25 years. The company $108 t$ $\$ 90,000$ in the transaction which 18 deductible in Tulis and if the corporation is in the higher excess-profita bracket, the cut in taxes would be considerable.

Thla sale must be able to stand up under the Bureau of Internal Revenue scrutiny.

Rental deduction. The A. B. C. Corporation has a building worth $\$ 150,000$ that it uses in 1ts business. The company declucts the annual depreclation on the building. The land has increased considerably since it was acquired by the A. B. C. Company. The present value of the land and buflaing comblned 1s $\$ 250,000$. The corporation undertakes a sole and lease-back. It includes in its flgures 1 ts annual rent, $\$ 25,000$ for the value of the land, which, under the tax law, could not have been amortized. 
The company pays a capital-gains tox on the prostt, but over a eriod of years the rental deductions of 11 wore than offset the tax pasd.

Thle type of deal was ourtalled by recent tax lawe. Under cartain conditions the rents from suah an arrangement are taxable to the charity landlara. If the corporation can ot12l find a buyer, this type of transaction et121 offers great posalbilities for tax avoldance. 2

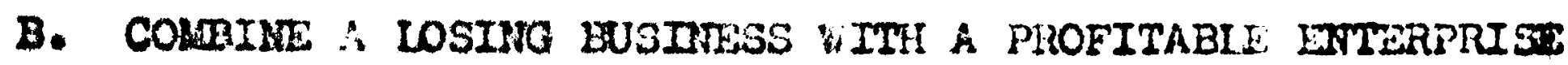

(Recently many business men have been looking for companios with a recerd of operating 10sese. Unprofitablo companies were pepular curing rorld War II and thoy are becoming increaeingly popular now. The rocsoning bahind thla udden interest in companies vith a record of operating loses is the tax recheing factor. Combine a losing business with a profltable bueinses and use the tax decucthons of the former to offeet the taxable incom of the latter.

Bualnesamen wo engege in this type of trancaction ahould canault section 129 of the Intarnal Reverue Code. The Commesioner of Internal Revemue may d1021 low any tax beneIts reculting rom this type of transaction if the principal purpose of the transaction was to evade or avold tax.

P. 83.

2 "Lose vith Profit," Buainese inek, Nay 5, 195I, 
If (1) any person or persons acquire, on or after October 8, 1940, directly, or indirectly, control of a corporation, or (2) any corporation acquires, on or after October 8, 1940, directly or indirectly, property of another corporation, not controlled, and the princ1pal purpose for which such acquisition was made 18 evasion or avoldance of Federal Income ar excess-profits tax by securling the benefit of a deduction, credst, or other allowance which such person or corporation would not otherwlse enjoy, then ouch deduction, credit, or other allowance ahall not be allowed. Control means the ownership of stock possessing at least 50 percentum of comblned voting power and at last 50 pergentum of total value of the stock of the corperation. 3

The U. S. Tax Court has taken the position that if the 1088 corporation retalns its basic ldentity it would be entitled to 1ts tax credite.

Two businessmen acquired a glove manufacturing corporation, moved the company's plant, and changed the type of article manufactured. They also renamed the corporation. The later corperation used net operating losses incurred by the corporation in its glove mafacturing business to offset income of the new type of business. The Commisaloner of Internal Revemue disallowed the deductions. In this case the U. S. Tax Court overruled the Commiseloner. The Court held that although the company's name had been changed, the operations of the company were still under the corporate charter of the glove company. They concluded that the corporation was the same toxpayer.

3 Internal Revemue Code (New Yorks Prentice-Hall, Inc., 1951), P. 2183 . 
Thls case was ruled on before section 129 became effective, but the court sald that it was doubtrul if the cection would have altered the decision.

Many tax men belleve that this declsion makes it safe to merge a profltable corporation into a 1089 corporation.

The principal reaconing behind this theory is that the 1088 company doesn't secure any benefits that it ald not have before.

The courts have generally held that when a 1088 corporation is absorbed by a profltable corporation, the two corporations are different taxpayers and the profltable corporation may not use the benefite recelved by the tranoaction. 4

C. DOING BUSINESS AEROND

(Vany corporations find that it 18 advantageous to do business abroad. Below are listed flve tax saving ways to do buriness abroad.

1. Corporations organtzed in a forel $n$ country doing business abroad.

2. Corporations organized in U. S. to do at least $95 \%$ of 1 ts business abrosd.

4 Wal1 Street Journal, May 28,1952, p. 1. 
3. Corporations organized in U. S. to do business - Leewhere in the 'estorn Hemisphere--Western Hemisphere Trede Corporations.

4. Corporations organlzed in U. S. doing business in certain U. S. possessions.

8. Corporations organlzed in U. S. under the China Trade Act to do buainess in China.

The tax advantage of doing business abroad has been emphasized in the last 10 years by the muge increase in United States Investments abroad.

(The amount of United States Investments abroad has Increased from $\$ 12$ billion to more than $\$ 19$ billion in the past 10 yeara. Th1s rapid growth is $11 k$ ly to oontinue die to the high tax rate on domestic corporations and under the Impetus given by Economic Cooperation Adminiatration and Mutual Security Agents projects for spending billions of dollars in European recovery.

1. Many U. 3. manufacturers have turned from exclusively domestic trade to selling their products abroad.

There are at least six posstble ways, elve of them tax saving, to organlze for dolng business abroad.

Nonresident foreisn corporations. The compantes are organlzed outside the United States, to do business anywhere in the world. The companies pay no U. S. tax 
on Income from foreign business.

The sale of goods must be made in a forelgn country to be exempt from U. S. tax. The sale 18 made at the locatlon where the seller surrenders all right, t1tle, and interest of the merchandise to the buyer.

Companies that qualify as a nonresident forelgm corporation are not subject to a tax for unreasonable accumulation of income.

Subsidiar1es. If the company in this group is a oubsidiary of a domestlc corporation, dividends recelved by the parent company are subject to normal tax and ourtax, but thay are full exempt from the excess profits tax.

The parent may also claim a portion of foreign taxes pald by the substalary. 5

Trading mostly abroad. These corporations are organdzed in the United States, but at least 95 per cent of their income is derived from sources abroad.

Damestic corperations, 95 percent of whose grose Income for the three-year perlod preceding the close of the tarable year (ar such part as the corporation was in exiatence) was derived from sources without the United States and 50 percent of whose gross Income is derlved from the active conduct of a trade or busis nss are epeciflcally exempt from excess-profits tax.

\footnotetext{
5 "Caching in on Foreign Trade," Business Veek, Marah 8, $1952, p$. 120. Coures (IN Yorki Prentice-Hall, Inc. Mitchell, Federal Tax
} 
These corporations are exempt from excess-profits tax, but they are subject to normal tax and surtax and for the penalty tax on unreasonable accumulation or earninge. Dividends recelved by the parent of a absidiary of this type are exampt from excess-profite tax and they are allowed an 85 per cent credit for normal tax and ourtax oomputatione.

Foreign tax credtt. Corporations in this group are also entltied to credit from taxes pald to forelgn countries. The taxpayer may treat the taxes pald to a forelon country as a credit or as a deduction, but he may not do both. The texpayer is entitied to change the election to treat a foreign tax as a credit or as a deduction at any time prior to the running of the statute of Iinftation.

Buch credit againat its income tax however, may not exceed that portion of the tax which the corporation"a narnal tax net income from the forelgn source bears to its entire normal tax not income for the same year.?

This 1inltation does not apply when you are taking the roreign tax as a decuction instead of a credit. The deduction might also be preferable when the corperation has a net 1088. It increases the carryover 1088 thet can be applied to income of prevlous and subsequent years. A credit In a loss year would be wasted, since you have no tax $118-$ b111ty to apply it against.

In1d. p. 3803. 
Wetern Hemisphere Trade Corporations. The Weotern Henlophere Trade Corparation is entitied to a elat 27 per cent credit in computing both normal tax and aurtax.

Western Hemiephere Trade Corporations are not subject to excesa-proflts tax.

To qualify in this group a corporation must meet the same requiremant as the corporations trading mostly abroad. They mast moet the 95 per cent forelgn gross income test and 80 per cent or more of gross incom must be derived from active conduct of a trade or business, Inntead of a 50 per cent minimum required for the corporations doing business abroad. AIl of the businass must be dom in the Hestorn Hemlaphere. 8

A Weotern Hemisphere Trade Corporation 18 a domestic corporation doing buainass entirely in North, Central, or South America, West Indles or Newloundland, wh at least 95 per cent of 1 ts gross incom anrived from sources outside the U. S., and 90 per cent Irom aetive trade or bualness.

The only way most domestic corporations can meet the 95 per cent gross income rule is to set up a new company to engage in forelen trade. One must be careful about the relationohlp of parent and aubsidiary.

The Bureau of Internal Reveme Insists that saleo among anch companies be booked in ine with prices charged to other buyors.

\footnotetext{
8 maching in on Farelgn Trade," Buslnesg Weok, uarah 8, 1952 , D. 520 .

Trank A. Dunn and Robert B. Mitche11, Federal Tax Coures (INow Yoosi Prent10e-Hiall, Ino., 1952), p. 3119.
} 
The beet method is to set up part of the enterprise as a soparate ent1ty, each paying 1 ts own expenses and $28-$ suning a falr ahare of joint conte such as adminlstrative orerhead.

\section{Corporation doing bubiness in U. S. posensalons.}

The corporation that is qualifled as a company trading mostly abroad or as a Hestern Hemiophere Trade Corporation may also be qualifled for this group. It may be an advantage if a company can qualify for this group.

This company is a domestic corporation that conducts the majorlty of 1 ts business in one U. S. possession. They pay tax only on Income from sources within the United States and on amounts recelved in the Undted States.

To qualify for this privilege, a company must derive at least 80 par cent of gross Income from a ginglo Unitad States possession over the past three years, and 60 per cent ar more of 1ts gross incom must come from active conduct of a business or trade within that possession.

The possessions on the Ilst are Wake, Midway, Johnson Irlande, American Samoa, Guam, Puarto R1co, The Canal Zone, and several other small 18land groups in the Pacifle.

It 18 possible that one of the companies wculd want to change Its qualiflcations and do business as a dfferent type or corporation. 
A corporation that qualifles as a company doing bualness in a United States possession may also qualify as a Viestern Henlsphere Trade Corporation if 80 per cent of 1 ta gross carnings come from the Canal ione or fucrto Rico and an additional 15 per cent comes from any other Vestern Hemlsphere Country except the United States. Thlo would sat1sfy the 85 per cent gross incomo requirement.

AIl incom from the 80 par cent possessions would be tax free, from U. S., and the belance of income would be reauced by the 27 per cent Western Hemlsphere Trade Corporation credit before computing normal tax and surtax.

To flt in the group doing business in U. S. posses1ons, a corporation must derive 80 per cent of Its gross income from only one possession, but the added 15 per cent requirement to put it also in the Western Hemisphere Trade Comporation group can be derlved from incom of several countries.

A corparation operating in a possession of the United States may also qualify as a corporation doing at least 95 per cont of its business abroad if 95 per cent of Its earnings come from one possession, or if at least 80 per cent come from one possession and the other 16 per cent comes from any other forelgn country.

China Trade Comporations. These compan1es are set up undar speclal leglslation for the China trade. 
Net Income recelved from China is credited against net income in computing normal tax and surtax.

These companles might offer great poesibilities under settled conditions. 10

10 warking in on Farelon Trade," Busineas Wen, Marah 8, 1852, p. 820 . 


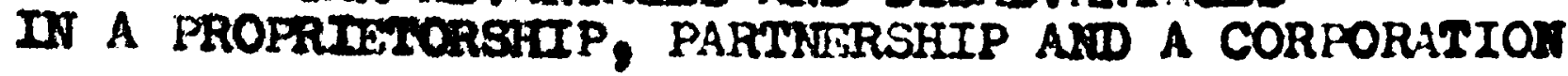

\section{A. CantaRnL ADVANTAGES AND DISADVANTIGES}

To determine which form would result in the lasst andual tex, compare, (a) the total income taxes of the partmars and (b) the aum of the imoom and excess-profite taxes on the corparation and the total incom taxes on the tockholdars.

In computing the taxes the following mut be taken Into consideration:

1. The Income of individual proprietarahlp and partmarahip is taxed at indivicual rates, regardless of whether left in the business or astributed to the individuale. Salaries are not allowed as a business expense.

2. There is a couble tax on corporationo-athe tax on the corporation plus the taxes on the stockholders. Salaries pald to stockholders are deductible to the corporation and income to the atookholder. Dividends are not decuctible by the copporation but thoy are inoom to atockholdars, and are therefore taxad twioe.

3. Salary and dividend polleles of a ecrporation cannot be based entirely on what the stookholders want. Sat aries are decturtible by the corperation only to the extent 
that they are reasonable. A peralty gurtax may be 1mposed on unreasonable accumiation of earnings, therefore, the corporation may be required to pay dividends.

Sale of interests. When an individual proprietor sells his business he usually sells it as a single unit, but he cannot report it as the sale of a single unit, he mat apportion the selling price between two classes of assets-a "capital" or "brdinary". It would be a distinct advantage to the taxpayer if he could apportion the total sales price to capital assets, because of the capitalgaine tax rate of 26 per cent compared to a mach higher rate that would be applied for the ordinary assets, Inventorles, to.

When a partner se $12 \mathrm{~s}$ hls interest in a partnerahip bo oells a single unit, too, but he does not have to apportion the sales price between alfferent assets. He pays the capital-gains rate of tax on the sale of h1s interest in the partnerahip. ${ }^{1}$

Capttal-gains and 10sses. The partnershlps and the individuals cap1tal-galns and losses are treated in the same manner. Each partner treats his distributable

\section{1 "How to Soften the Tax Blow," Business ieck,} July 24, 1951, p. 73 . 
share of partnerahips capital-gain or 1088.

In the case of a corporation's capltal gain a different method of handing capital-gain 18 required. A corparation's cap1tal-gains may be offeet by its own capital 2088e8, but the stockholders cannot offset corporate losses against his personal cap1tal-gains. The corporation recelves the benefit of a lower effective rate under the alternative method on its net long-term capital-gains in excess of any short-term capital 10sses, but the excess of long-term cap1tal gains will again be taxed to the stockholdor as ordinary insome where distributed by the corporation as dividends. 2

\section{Changing the form of businese. The tax 1lability}

arloing from a change in the form of business will vary apending upon many factors-the extent to vihlch business assets have depreciated or appreclated in value and the use of tax aroiding methods.

No recognized gain or loss need be entalled in a transfer from a partnerahip to a corporation if the nonrecognition provision is complied with. But a transfer from a corporation to a partnership alwaye reaults in a recogaized gain or 1083 .

\footnotetext{
2 Frank A. Dunn and Robert B. Mitchell, Fedoral Tax Couree (Rew York: Prentice-HaIl, Inc., 1952), p. 3124.
} 
Trangfer from a partnerghip to a corporation. There Is an Imnediate tax advantage to partners when assete that have appreciated are transferred to a corporation. The effect of ouch transfers may merely defer taxes. If the corporation bells the appreclated abeets they retain the same basls as they had to the partners.

Partners do not enjoy any Immediate tax advantage when deprealated assets are transferred to a corporation. If the 1008 was recognized, the partners would be able to offet the losses against elther ordinary incom or capitalgalns dopending upon the nature of the assets transforred. 3

Trangfer from a corporation to a partnorsintp. A corporate Ilquidating dividend 18 incurred when assets are transferred from a corporation to a partnarahlp.

All gains are regarded as carital-galm, elther chort-term or long-term.

A long-range tax advantage my occur, because the partnerahip's basls of the trangferred assets is the value at the tim of Ilquidation.

An immediate tax advantage may arlse when depreclated asects are transferred by the corperation to the partnorahip If the ahareholders are able to utilise their capltal 10sees

3 In14., p. 3125. 
ourrently or in future carry-over years to offset capital gain. 4

\section{B. SALE OF COMPANY}

Imreatigate the possibilitien, when you start flling tax data on the sale of your bualness, of a transaction that w111 save you tares.

There are several places in the tax laws where the tax payer may make a cholce in completing a business tranaaction.

There are often several legltimate ways to report a secific transaction. If you choose the proper one It can mean the difference between paying a large tax and paying a mall tax or none at all.

There are three different sets of rules, depending on wether the business is (1) a sole proprietorahlp;

(2) partnarship; or (3) a corporation.

Proprietorahip. Whan an individual proprietor aells his business he usually sells it as a single unit. But he cannot repart it as the sale of a single unit, he must apportion the selling price between two classes of assets"capltal" or "ordinary". It would be a dlstinct advantage to the taxparar if he could apportion the total sales price 
to capltal assets, because of the capltal-galns tax rate of 26 per cent compered to a much higher rate that would be applied for the ordinary assets-inventorles, etc.

The sellex should examine each asset to determine Whether the galn or 1088 from the sale 18 "capltal" or "ordinary".

Assets may be compared with the following table. 5 TYIDE OF ASSET 1. Oadinary Asset

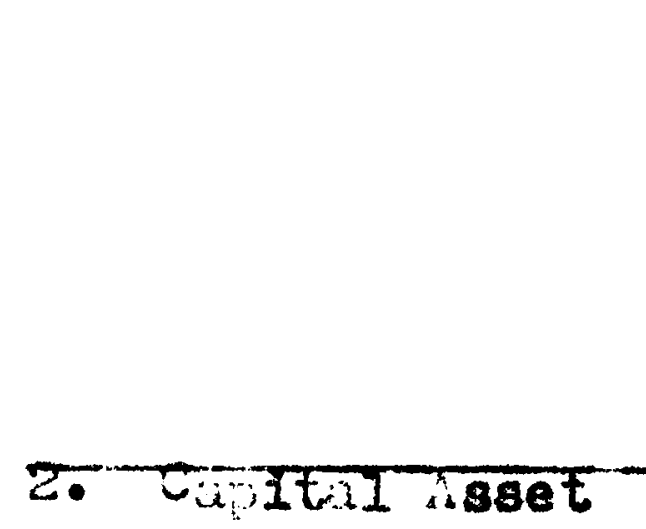

\section{Property included in} inventory.

Land, bullaling, and other copreciable property used in the business and held Iese than $81 x$ months.

can

Stock, bonds, and other securities-except when they are part of the stock in trade of a dealer.

Land, buildings, and other property not used in the business.

Goodurl11

Accounts and notes receivable and trade acceptances arloing rrom sales.

5 "How to Sorten the Tax BIOW," Business lieek, JuIy 14, 1961, p. 73.

Sales of thece assete result In ordinary incows or 1088. Galns are taxed In rull.

Losses are dechuetible in rull.

5ales of these assets always recult in capltal gains or $1088 e 8$

\section{?}



3. Dopreciable
Cosets
Land, buildings, and doprealable property, uned in trade or business and beld more than six months.
If sale recults in a gain, it ic treated an a cap1tal gain, but is cale reculto In a 1080 , it 18 doductod in ruli.

Ordinary gains or 108008 are treated fust as regular bualnose income. Gain or 2088 from the sale of a capital asset is wbject to the capltal-gains tax of 26 per cent. The seller would cone out best taswlse if he could allocate all of hls gains to capital assets and all of hls 108ses to ordinary assets. If this is dom, the Jureau of Internal Revenue can refuse to accept it and may oubet1tuto 1ts own allocation. The seller should draw up a dotalled contract of eale emumerating the cash, account recelvable, Inventory, goodwill, etc. If this contract is drawn up in good falth, the Bureau of Internal Reveme will unalis accept the allocation as made by 1 ts content.

One way to avold taxed is to trnnsfer the buninese to a corporation, tax-free, in exchange for corporate stock. If the Individual sell the stock at a later date he may take a capital gain on the entire profitm-corparate stock is a capltal asset. If the transfor was in anticipation of Immadiate sale of the stock, the Bureau of Internal Reveruse may challenge the validity of the transaction, 6

\section{ID14., p. 24.}


Partnersh1p. Ont1I 1950 the Bureau of Internal Revenue has argued that the salo of an interest in a partnerahip 1nvolved the same :rinciples as the bale of a 8010 proprietorahlp. The courts contimued to hold that the sale of an interest in a partnorahip was a sale of a capital asset and the Bureau Ifrally agreed.

The case of the Commisaloner of Internal Revenue v. Max Sharipo in 1950 wa one of the factors that made the Bureau change 1ts way of reasoning.

Staripo sold his partnorahip interest, at a profit to one of the other partners. He reported the entire proflt as the sale of a capital asset. Tho Bureau of Internal Revenve contended that when a partner sells his interest in a partnership, he merely sells his share of the partnership aseats. The Bureau attempted to apportion the assets between "ordinary" and "capitel" assets as it would in the sale of a sole proprietarohip.

A U. S. Court of Appeals decided in favor of the taxpayer and allowed the capltal gain taken by him.?

The Bureal now takes the position that the sale of an Intarest in a partarsin is the sale of a capital asset. An indivicual partner's interest in a partnerah $1 p$ Is a capital asset. Thus, the sale of a partner's interest in a partnerahip conetitutes the single sale of a capital asset, and ahould not be treated as the sale

7 Iold., p. 76 . 
of the partner's share of the individual assets (such as land, bullalings, fixtures, inventory, accounts recelvable) comprising the partnership business. Note that this rule 18 opposite in effect to the rule governing the sale of a business as a whole which applies to sole proprietors. 8

If the partners in a businoss 3011 the ent1re partnership, dfferent methods of sale tay have afferent resulto. This is shown by the decision in the Luhrs case.

Mrs. Luhrs and her family operated a business as partners. They sold the partnership to outsiders. The transaction was carried on entirely in terms of a sale or the partnership interests of the family. The partnerahip nam was not tranaferred.

The family reported the transaction as a sale of capital assets, but the Bureau of Internal Revenue contested the treatment. The Tax Court overruled the Bureal and held that the Luhre had actually sold interests in the partnerahip. The court cited another case, where die to the negotiations and contract of sale, It had ruled that the partners' IntentIon had been to sell assets rather than tholr Interests in the partmerahip. 9

Comporation. Corporate stock is a capltal asset. The selier of an incorporated business has no problem of allocation if he sello the stock. Purchase of stock may

\footnotetext{
9 "How to Sorten the Tax BIOW," Business "ileek, July -2t, 1961, pe 76.
} 
involve extra taxes for the buyer. Buyers may not be willing to handle a transaction in that manner.

A double tax llability is imposed when the corporate assets are sold--the corporation pays a tax and then the cor-

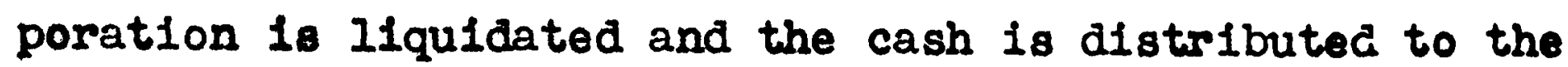
stockholders, they must pay a capital gains tax, cn the difference between the cost of their stock and the amount they recelve in IIquidation. 10 The firat tax may be avolded if the corporation distributes the assets in kind to the stock holders.

If the corporation does not sell the assets, but distributes the property to the 8 tockholders in complete or partial liquidation of their holdins and the distributed property is sold by the stockholders, only one tax or deduction is involved--tax or profits realized by the stockholders, or the deduction of the 1088 to the stockholder. 11

\section{OPERATIMG A FAMILY BUSINESS}

Many small business men may find angles to avold taxes If they choose the right type of business. The family business provides a good example. The chart on page 63 gives an examplo of the differing effects of $t a x e s$, in terms of three types of business organization--proprletorship, partnerahip, and corporation. 12

10 m1d., p. 76

11 Frank A. Dunn and Robert B. Nitchell, Federal Tax Course (New York: Prent1ce-Hall, Inc., 195\%), p. 3113. 12 "How to Save on Taxes," U. S. News and World Report, May 30, 1952, p. 62 . 
As a Proprietorship?

Husband (owner)

Salary $\$ 5,000$

Profit $30,000 \quad \$ 15,524 \quad \$ 24,476$

Wife (employee)

Silary 5,000

Son

$\boldsymbol{1 1}$

Salary 5,000

1,052

3,948

Deughter "

Salary 5,000

1,052

3,948

Totals

$\$ 50,000$

$\$ 17,628$

$\$ 32,372$

As a Partnership?

Husband (owneremployee) Profit $\$ 12,500 \quad \$ 3,754 \quad \$ 8,746$

Wife

n

" 12,500

3,754

8,746

Son

"

" 12,500

3,754

8,746

Daughter

n

1 12,500

3,754

8,746

Totals

$\$ 50,000$

$\$ 15,016$

$\$ 34,984$

As a Corporation?

Husband (stockholder- Salary $\$ 5,000 \quad 1,052 \quad \$ 3,948$

Wife

5,000

1,052

3,948

Son

II

5,000

1,052

3,948

Daughter

n

5,000

1,052

3,948

Corporation "

Profit 30,000

10,100

19,900

rotals

$\$ 50,000$

$\$ 14,308 * \$ 35,692 *$

*Assumes all profit is left in the business. If profit is all paid out in dividends, on which stockholders are taxed, total taxes become $\$ 20,974$, and earnings after taxes $\$ 29,026$. 
The fanily business used in this example has an anmal net incane, before taxes, of $\$ 50,000$. Four members compose the fantly business group, each draw a salary of $\$ 5,000$ a year.

\section{Operating as a proprietorghip. Th1s firm will pay} out a larce percentage of its earnings for taxes, due to the fact that the proprietor and his wife will pay on their $\$ 10,000$ incom-the company's $\$ 30,000$ in profits and a $\$ 5,000$ ealaxy for each. According to the chart on page 63 the proprietor and h1s wife mast pay $\$ 16,525$ of their $\$ 40,000$ incame in taxes. After taxes on the salaries of the son and daughter, the company keeps only $\$ 32,372$ out of 1 to $\$ 50,000$ Income.

Qperating as a partnerghip. The famlly must still pay taxes at indivicual income tax rates, but the $\$ 50,000$ in profits will be divided equaliy among the four members of the fam1ly.

By transferring the family business from a propriotorahip to a partinerahip, the famliy w111 save $\$ 2,618$ in taxes. The proprietor who transfers his business to a partnerahip, may have to pay gift taxes if he makes gifts of the Interests to the mombers of his family.

Qlft taxes are much lower than income tax rates and the amount pald out in gift taxes wolidd be offeet in later 
yeare by tax saving resulting from the tranafer. ${ }^{13}$

onrating ae a corporation. If the family leaves the corporate profite in the corporation, the family bueInese will be texed at lower rates. If they take the profite out of the remily buainess thoy will pay a highor rate of tares.

If the femily leaves the earninge in the businose they will keep $\$ 3,320$ more of Its Incom than if It were a proprietorsh1p. 14

$\quad 23$ mide, p. 65 
CHAPTER VI

ESTATES

The Federal Estate Tax. Two Federal Estate Taxes are actually imposed, the Basic Estate Tax and the Add1tlonal Estate Tax. The purpose of the Basic Estate Tax is the computation of the smount of credit allowable for estata, inheritance or death taxes pald to the states and to forelen countriea. A specific exemption of $\$ 100,000$ is allowed for the purpose of computing the Basic Eatate Tax.

The estate subject to the Basic Estate Twx is 3180 subject to the idditional Estate Tax. A peciflc exemption of $\$ 60,000$ is allowed for the purpose of computing the Addtlonal Eatate Tax.

The following two charts give the Estate Tax rates on estater not exceeding $\$ 500,000.1$

Basic Estate Tax Rater

1 percentum of the amount of the net estate not In excess of $\$ 50,000$,

2 percentum of the amount by which the net estate exceeds $\$ 50,000$ and does not exceed $\$ 100,000$;

3 percentum of the amount by wich the net estate exceeds $\$ 100,000$ and does not exceed $\$ 200,000$;

4 percentum of the amount by wich the net estate exceeds $\$ 400,000$ and does not excesd $\$ 600,000$.

1 Internal Revemue Code (New York: Prentice-Hall, Inc., 196I, p. 1801. 
Additionil Estate Tax Rates

If the net estate 18:

The tenative tax shall bes

Not over $\$ 5,000$

$3 \%$ of the not estate

Over $\$ 5,000$ but not over $\$ 10,000$

$\$ 150$, plus $7 ;$ of excess over $\$ 5,000$

Over $\$ 10,000$ but not over $\$ 20,000$

$\$ 500$ plus 12,5 of exce 83 over $\$ 10,000$

Over $\$ 20,000$ but not over $\$ 30, \infty 00$

$\$ 1,600$, plue $14 \%$ of excess over $\$ 20,000$

Over $\$ 30,000$ but not over $\$ 40,000$

$\$ 3,000$, plus $18 \%$ of excess over $\$ \$ 0,000$

$\$ 4,800$, plus $22 \%$ of excess over $\$ 10,000$

$\$ 7,000$, plus 25\% of excess over $\$ 50,000$

$\$ 9,500$ plus $28 \%$ of excess over $\$ 60,000$

$\$ 20,709$ plus $30 \%$ of excess over $\$ 100,000$

$\$ 65,700$, plus $32 \%$ of excess over $\$ 250,000$

Over $\$ 250,000$ but not over $\$ 500,000$

A. ESTATE PLANNING

Planning the estate means the preservation of the estate, not for the owner but for those who he wlahes to leave it to after his death. The tax aspects of estate planning is the only objective presented in this study. Individuals wishing to plan their estate may be divided into three classes, depending upon the size of the estate. 
Estaten 2 Irom 11 milzion upward. There are a very fow eatates of this olze in the country. After an estate reaches $\$ 1$ million, the rates rise until the government is taking as much as 77 per cent. 2

Orners of estates this large must have the advice of a private otafe of tax lawyers, property lawrers, investment counsellors, accounting advisors, etc. to maintaln such an eatate. The estate would be planned for the future by these experts.

Estates of from $\$ 100,000$ to $\$ 250,000$. The main prob lem of people in this estate bracket, is to make certain that their testamentary wiahes are wisely accompliahed within the framework of the estate and gift tax exemptions and excluslons. Particular attention ahould be devoted to removing property from the estate by "Intervivos" gifts.

The estate tax on a net estate of $\$ 200,000$ would be $\$ 32,700$. If the person gave away one-half of the estate by oreating a legal truat, he would save about $\$ 28,000$ in estate taxes and pay a gift tax of only $\$ 10,000-a$ net saving of over $\$ 26,000$. Th1s would leave an estate tax llab1lity of approximately $\$ 4,700$. With this comparatively amall tax

2 Hugh C. Beckeord and Robert $u$. Weston, "planning the Eistate," Taxes, The Tax Magazine, 30-7, July, 1952 , p. 527 . 
liability it might be wise not to attempt to avold taxes further.

\section{Estaten of from $\$ 250,000$ to $\$ 1$ m11110n. In this}

bracket, the tax burden becomes large enough to deprive an Individual's beneflclaries of the very protection that is paramount in his mind. The tax on an estate of $\$ 500,000$ amounts to approximately $\$ 126,600$. If a man's estate conbists entirely of a going business concern and he has not planned his estate, ralaing $\$ 126,000$ might banterupt the business.

Example of estate-planning. Jim Brown has accumulated a net estate of $\$ 500,000$ also, he has declded to plan his estate with the aid of an expert tax consultant.

Jim Brown's business is a corporation and he owns all of the stock. The net earnings are about $\$ 50,000$ a year. The stock of the corparation has an estimated value of $\$ 460,000$. The company has a bank balance of $\$ 60,000$, which 1s the major part of 1ts working capital. If the beneflelaries withdrew any more than this it might impalr the business.

Jim has drawn enough salary through the years past to IIve comfortably. He has a hom that is valued at $\$ 60,000$. He carries $\$ 60,000$ in ife insurance whtch is payable to his wife. H1s gross estate would be valued at $\$ 580,000$. The 
cost of administering h1s estate 111 amount to $\$ 45,000$, and he has debts of $\$ 35,000$. Accordingly, his net estate can be estimeted at $\$ 500,000$. If $\mathrm{JIm}$ does not plan his estate and leaves It all to hls chlidren, the estate tax will amount to $\$ 126,600$. The immodiate payment of such an amount will require the Ilquidation of corporate assete, whlch are essent1al to the business, and the result may be a forced I1quidation of the corporation.

Before undertaking the takk of planning the estate the tax conoultant must know $J \operatorname{Im}^{\prime} s \mathrm{llf}$ and family as well as his assets.

In estate-planning three factore mast be considereds (1) the lack of I1quidity of the estate, (2) the dealre to protect the fam1ly, and (3) the dealre to contime the bueiness with the least possible disruption.

By estate-planning, these and similar problems can bo colved. The amount of estate tax payable on Jim Brown'B death can be aharply reduced. H1s arfairs can be put in weh order that he 18 relatively sure of perpetuation of the family business in the hands of his beneficlaries. The assets in the eatate need not be sold at forced sale prices to met taxes.

B. WORKING TOOLS THAT MAY BF USED IN ESTATE PLINNING elfte "Inter refrog". A gift "Inter vivos" I1taraly, 
Is one between the Ilving, where one pereon makes a gift to another.

Under the present Law, the donor may exclude the first $\$ 3,000$ of gifts made to any one donee during the calendar year. Thus if a donor in 1952 made individual gifts of $\$ 3,000$ in cagh to ach of 10 relatives (total of $\$ 80,000$ ), there would be no gift tax Ilability unless the donor made additional gifts to the same relatives in the same calendar year. The individual exclusion is an annual allowance. In addition to the annual individual exclusion the donor is allowed a opeciflc exemption of $\$ 30,000$ against the total amount of his gifts. Thls exclusion may be used only once. 3

There are two in tax advantages in making giftei 1. Assets are removed from the high brackets of estate tax even if the indivicual exclusion and the opecifle exumptions are exceeded, gift tax rates are lower than e8tate tax rates. For instance the glet tax liablilty on $\$ 100,000$ would be much lower than the estate tax 11ab1l1ty of the same amount.

2. Gifts remove the income of the property from the donor's high income tax brackets and put ouch income into the relatively lower brackets of the donees.

3 Brank A. Dunn and Robert B. M1tchell, Fedoral Tax Couren (itẹ York: Prentice-Hall, Inc., 1959), p. 4212. 
Glfte for tax purposes my be outright or in trust. In order to remove the trust property from the grantor's taxable estate, the trust must be in ach form that the following requirements are mets

1. The trust mast be irrevocable.

2. Income from the trust mut not be reserved for the grantor.

3. The grantor must not reserve any benef1ts or controls which is equivalent to income.

4. There can be no ohort-term disposition within the fam1ly conomic unlt, whereby the granter has reserved economic bener1ta.

6. The trust will be incluaible in the grantor'. estate if (a) duration is moasured by the donor's 11fe, or (b) the trust must not terminate during the grantar's $11 f^{\circ}$. 6. The glft must not be made in contemplation of death.

The past point is of utmost importance in forming a trust or making a gift outright. The conor mast be in falrly good health at the time of making the gift or the Treasury Department will include the glft in the grose estate.

A proper estate program should include provis lons for making additional gifts to the trusts. If the donor used h1s $\$ 30,000$ spee1flo examption in forming the trust, 
he may otili use his $\$ 3,000$ individual exclusion anmally or with his wife's consent he may include her individual excluion in making gifts. Uaing both anmal exclusions he my make a total of $\$ 6,000$ in gifts to the trust anmaly."

Merital deduction. The Revemue Act of 1948 added this provision, relating to deductions, to allow within certain IImite a decuction for the value of property paseing at ceath to a arviving spouse. This provision is known as the maxital decuction.

The purpose of this deduction is to equallze estate taxes between residents of comminfty-property states, ouch as Texas for example, and residents of non-community-propexty states.

The amount of the accuetion 18 ilmited to 50 per cent of the adjusted gross estate.

Example: Jim Brown has a gross estate of $\$ 675,000$. Debts, administration and other expenses amount to $\$ 76,000$. The marital decuction 18 computed as follows

1. Gross estate

$\$ 675,000$

Le8s:

2. Expenses

75,000

3. Adjusted gross estate

600,000

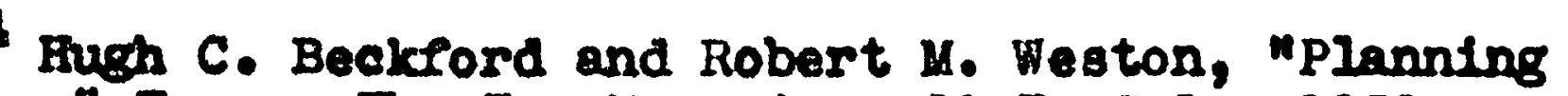
the Estate," Taxes, The Tex Magazine, 30-7, July, 1952, p. 532. 
4. He Marimin mar1tal deduction (50 per cent of adjusted grose estate)

300,000

The marltal docuction is allowed only for property or interests in property that pess to the curviving spouse. Property recelved by the following ways passes to the ourviving spouse and they may qualfy for the marital decuctions

1. If the property or interest in property in a bequest or device from the decedent.

2. If the property or interest in property is in herited from the decedent.

3. If the property or Interest in property is the dowry or courteay interest of the surviving spouse, where auch exist.

4. If the property or Intereat in property bas been transfexred to the surviving spouse by the decedent at any time.

6. If the property or interest in property was held by decedent and ourviving apouse as joint owners with right of survirorahip.

6. If the property or interest in property passes to ourviving spouse by virtue of the exerc1se, non-exerclse or release of a power of appointment held by decedent. * 7 . If the property or Interest in property consists of proceds of inmurance on decedent's ife recelvable by 
the ourviving epouse. 5

Jin Bromn is expected to leave a net estate of

$\$ 600,000$. If his heirs pay estate tax on the whole amount, the tax will be $\$ 126,000$. If he passes one-half of the e8tate to his w1fe- $\$ 250,000$, the estate tax will be $\$ 47,500$. Through the maritel deduction alone, the estate which he leaves saves $\$ 78,000$. If his wife should die a few years Inter and st111 have the $\$ 250,000$, her estate taxes would be about $\$ 47,500$, and the two estates together w1ll pay approxImately $\$ 95,000$. The not saving in estate taxes would be around $\$ 31,000,6$

The following chart gives an examplo of tax savings by the use of marital deduction. 7

\begin{tabular}{|c|c|c|c|}
\hline $\begin{array}{c}\text { Eatate } \\
\text { Before } \\
\$ 60,000 \\
\text { Exempt10n }\end{array}$ & $\begin{array}{c}\text { Tax } \\
\text { Without } \\
\text { Larital } \\
\text { Deduction }\end{array}$ & $\begin{array}{c}\text { Tax } \\
\text { With } \\
\text { Marital } \\
\text { Deduction }\end{array}$ & Saving \\
\hline $\begin{array}{r}\$ 100,000 \\
200,000 \\
260,000 \\
300,000 \\
350,000 \\
400,000 \\
500,000 \\
760,000 \\
, 000,000\end{array}$ & $\begin{array}{r}4,800 \\
31,500 \\
43,500 \\
59,100 \\
73,300 \\
87,700 \\
116,500 \\
191,800 \\
270,000\end{array}$ & $\begin{array}{r}\$ \\
4,800 \\
10,700 \\
17,500 \\
24,400 \\
31,600 \\
45,300 \\
80,000 \\
116,500\end{array}$ & $\begin{array}{r}4,800 \\
26,700 \\
34,600 \\
41,600 \\
48,900 \\
56,200 \\
71,200 \\
111,300 \\
153,800\end{array}$ \\
\hline
\end{tabular}

5 Frank A. Dunn and Robert B. Mltche II, Federal Tex Couree (Yew York: Prentice-Hall, Inc., 1952), p. 4122. 6 Buch $C$. Beckford and Robert $u$. Weston, "PIanning the Estat, " Texes, The Tax Magarine, 30-7, July, 1952, p. 532. p. 136. 
Trusta. Property may be left in trust for a ourviving epouse's benefit and the marital decuction will be allowed if the following conditions are met:

1. If the spouse is entitled for Iffe to all the Incom, payablo at least anmally.

2. If the beneficlary spouse has a taxable power of appointment exercleables

a. During 11fe

b. At death

For martal deduction purposes, property 18 doemed to pass to the surviving spouse if it passes to his or her estate. Thus, a marital deduction would be allowed for the corpus of a trust payable to a wife's estate on her death. 


\section{CHAPIHR VII}

\section{BUMOCAKY}

The purpose of this chapter 18 to present a brier over-all pletare of the study and to narrate the finainge of the otudy in broad general statements. Speciflc examples have been given in the body of the study to support the statements contained in this chapter.

Th1s study has not attempted to cover all of the possible ways and mans of tax avoldance and evasion. Only some of the most prominent ones are discussed.

The methods of tax avoldance and evasion presented In this study are based on recent articles in bisiness and professional magazines.

During the past four decades tax avoldance and evasion have become of paramount importance to every taxpayer in the United States. As tax rates increased, taxpayers sought new means of avolding taxes.

The firat major attempt to prevent tax avoldance was the passage of the revenue Act of 1932. Congress, In this act, enacted mumerous provisions designed to prevent tax avoldance.

In the first chapter of this study, a brief history of the Revenue Acts was presented.

The Revenue Act of 1913 marked the beginning of the 
tax on Incom in the United States.

Taxes Increased sIlghtly untll 2924 and thon they were decreased unt1 1 1932. In 1932 teres began to gradually Increase unt1I 1940 and they were decreased again. From 1940, taxes have risen sharply with a few decreases.

This study has fresented methods used to avold and ovade taxes by individusa 18, partnershipe, and corporations.

In the case of Individuals the following method were Alscussed: capltal galns--proflt-sharing plans, stock option, a Panamanian Corporation, and Investments; deferred salary plans; expense accounts; loans; postponing income unti2 1952 and propaying 1953 expenses in 1952; insurance pl ns; stock dividends; and the creation of trusts.

The third chapter discuseses the tax adrantages and disadvantages of a partnerahip and also the famliy partnerchip.

The fourth chapter alscusses methods employed by a corperation to avold taxes.

The flfth chaptar presents a brief discussion on the tax advantages and disadvantages of (I) a propeletorahip, (2) a partnarahip, and (3) a corporation.

The 1xth ohapter discusses estate planning and glves an example of how an estate might be planned. 
Tax avoldance and evasion is an ever present and changing concept. 18 Congress closes existing loop holes In the tax laws, tax men find new ways to avold taxes. At the present time, tax avoldance and evasion 18 of paramount importance to all. In the last two decades, due to ever increasing taxes, tax men have employed every concelvable means at their command to save on taxes. Some business men use legal means, some use 121 gal means to preaerve their capital.

If the trend contimies as it has in the past, taxes are Increased when the Government needs more revemue and decreased when the Government needs less revemue or to ablalze the nation's economy. Tax evasion costs the Government about $\$ 1$ b11110n anmally. The Government's needs require a certain amount of income texes to be pald annualiy. It 18 possible that revenues lost by the Government through tax evacion w1ll have to be made up by the honest taxpayer by increased taxes.

fox avoldance is a legal means employed by a taxpayer to preserve his capital and to preserve his estate Ior his heira. 


\section{BIBLIOGRAPHY}

\section{BOOKS}

I L Dunn, Frank A., and ultchell, Robert B. Federal Tax Course, New York: Prentlce-Hall, Inc., 1952.

Internal Revenue Code, New York: Prent1ce-Hall, Inc., 1951.

w Lowe, J. Blake, and Wright, John D., MInimlzing Taxes on Incomes and Estates, New York: Barron's Publiahing Co., I937.

(1) Ratner, Sidney, Amorican Taration, Boston, w. i. Norton and Company, Inc., 1942.

\section{PERIODICAL ARTICLES}

(1) illison, John P., "How Investors Can Cut The 1r Texea," Fortune, $45^{\prime}$ (Apr 11, 1952), 96.

Beckeord, Hugh C., and Weston, Robert M. "Planning the "Estate," Taxes, The Tax Magazine, 30-7, (July, 1862). 527.

"Cashing in on Forelgn Trade," Buglness "Jeek, (March 8, 1952), 120

(2) - "Cut Taxes--Save for Future," Business :leek, (February 23, 1952), 141.

Dlerherger, Wegley A., "Income Splitting and Famlly Partnerships," Taxes, The Tax Magazine, 30-7, (July, 1952), 520.

"Estate Splitting," Buglness leek, (Jamary 26, 1952), 136.

"How Taxes Are Avolded," U. S. News and vorld Report, (March 21, 2951), 56.

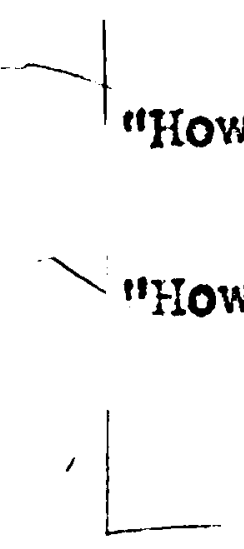

to Save on Taxes," U. S. News and "orld Report, (May 30, 1952), 62 . to Soften the Tax Blow," Business eek, (July 14, 1951), 
81

4

Tlasser, J. K., "Higher Income, H1gher Taxes," The Atlant1c Monthly, 189-3, (March, 1952), 65.

Lasser, J. K., "How to RaIse Executives' Take-Home Pay Under Wage Control and Tax Laws, The Journel of Accountancy, 93-2, (February, 1952), 166.

"Lose With Prof1t," Business Keek, (May 5, 1951), 83.

"Hake Your Boy a Partner," Buginess "icck, (December 1, 1951), 84.

"Ralaing Pay for Top Mens ways for Saving Taxes," U. S. News and world Report, (June 6, 1952), 77 .

"Start Getting Ready for Iower Taxes," Business leek, (Way 3, 1952), 87.

\section{NEYSPAPERS}

Hal2 Street Journal, May 29, 1952, 1.

Ya11 Street Journa 1, June 4, 1952, 1.

Wal1 Street Journgl, June 18, 1952, 1 . 

